\title{
Does Learning, Development and Work Life Balance Affects Happiness: A Moderated Mediatory Model
}

\author{
Muhammad Haris Ullah (Corresponding author) \\ Karachi University Business School (KUBS), University of Karachi \\ KU Circular Road, University of Karachi, Karachi, Pakistan \\ E-mail: harisullah1506@gmail.com \\ Dr. Danish Ahmed Siddiqui \\ Karachi University Business School (KUBS), University of Karachi \\ KU Circular Road, University of Karachi, Karachi, Pakistan \\ E-mail: daanish79@hotmail.com
}

Received: February 23, 2020 Accepted: April 8, 2020 Published: April 10, 2020

doi: 10.5296/hrr.v4i1.16615 URL: https://doi.org/10.5296/hrr.v4i1.16615

\begin{abstract}
Keeping the workforce happy is a major issue faced by today's employers. The big challenge is to find what job-related factors can lead to happiness, the bigger challenge is to identify the sources that lead to happiness. We proposed a theoretical framework based on the research of (Joshanloo \& Jarden, 2016) which studied hedonism as a major cause of happiness when moderated by individualism. We further extended the model, including career related goals that effect hedonism. Hence, we theorized that, work life balance, career development, learning affect hedonism, which subsequently effects happiness. Moreover, individualistic societies are proven to be more hedonistic (tend to value pleasure) and are more closely linked with happiness as compared to collectivist societies. Empirical validity was established by conducting a survey using a close ended questionnaire. Data was collected from 219 respondents from different organizations of Pakistan and was analyzed using confirmatory factor analysis and structured equation modeling to test the hypotheses testing the impact of all three career related factors to see how significantly they affect hedonism, which would ultimately have an impact on happiness. Results indicate that Individualism plays a significant positive role on happiness, as well as in directly, is it negatively complements the
\end{abstract}


inverse effect of Hedonism on Happiness. Findings imply that the career related factors positively affect hedonism that would in turn bring more happiness. Most importantly, seeking pleasure is necessary to bring happiness. This study will benefit organizations working in Pakistan to identify the valuable sources of keeping their employees happy.

Keywords: Happiness, Hedonism, Individualism, Work life balance, Career development, Learning

\section{Introduction}

\subsection{Background to the Study}

Happiness is an important element in everyone's lives and is a source of satisfaction and positivity. There are many sources to ignite this positive feeling, and one important source is through doing what is essential to the society. Knowing community," collective mind conditioning" which separates representatives of one society's motives and actions from those of other societies is therefore important if we are to understand the different causes of happiness (Valente \& Berry, 2015). Happiness, also known as positive psychology, is not only an important factor in one's personal life, but also plays an essential role in the professional lives, and hence, is an important element for business performance and productivity. Employee wellbeing should be a significant concern for enterprises, because of its strong association with job productivity which ultimately leads to stronger performance by managers. (Layous \& Lyubomirsky, 2015).

Happiness is not only the essential source of employee wellbeing in the workplace, but there are several other drivers of that lead to a better working environment. An example of such drivers includes career development prospects. Career development, known as career-related affective well-being, relates to the subjective feeling of workers about the positive or negative effect of carrying out specific work activities in a given environment in existence. (Zheng, Kashi, Fan, Molineux, \& Ee, 2016). Career Development is a crucial factor that attracts an employee towards any job or position in an organization, in fact, the future career direction is considered as a priority by many when opting for a job. (Goffee \& Scase, 1992).

Another important element for an employee's well-being is work life balance. Lately, the discourse on work-life balance has established the need for improvement in the working conditions. In answer to these debates, research has been conducted which explains the creation and evaluation of a succinct measure of work-life balance based on people's observable behaviors. In addition, the correlation between work-life balance and retention habits is greater than the connection between job satisfaction and harmony (Brough et al., 2014).

Along with these elements, learning is also a key player of an employee's well-being and is important for progressing one's career forward. Although the above-mentioned elements of happiness, career development, work life balance and learning have been identified as essentials in a work place; there is yet to be research that brings them together on the same platform to be studied relatively in the context of one another.

It is important to note that the impact of each variable on happiness may vary from person to person and depends on the fact of how much each is valued or found satisfying; also known 
as hedonism. Hedonism is the belief that a good life consists mainly of feelings of gratification (Tugade, 2004), but what one is grateful or thankful for depends on their norms and cultural values. The culture a person is associated with plays a crucial role in shaping their beliefs. Cultures do not embrace hedonism in the same way. In fact, various researchers have discovered that hedonism tends to be more associated with collectivism form of culture as compared to the ethic of individualism (Joshanloo \& Jarden, 2016) Furthermore, it has also been observed that collectivistic societies are typically more conservative than individualistic cultures and seem to focus on harnessing hedonistic impulses and upholding certain popular ideals that focus on self-discipline (Diener, Tay, \& Myers, 2011).

\subsection{Problem Statement}

The modern problem needs modern solutions. The happiness of employees in any workplace reflects on their work and their performance. If an employee is happy, he will surly contribute positively and will be productive for an organization, which will result in the achievement of potential goals set by organization, driven by its mission, vision and its core values. In a nutshell, achieving happiness of an employee at workplace is the key factor for the successful accomplishment of the Organization's set objectives.

With the growing number of organizations around the globe, focus on the well-being of the workforce in their work environment is now a common subject of theoretical concern and expanded study. The wellbeing of an organization is defined as the manner in which its workers view its job function and efficiency (Warr, 1992) it covers the physical and mental condition/wellness and well-being of the person and the feeling of satisfaction as these are all linked to work-life balance (Grant, Christianson, \& Price, 2007).

It was noted that workers who have established negative views on their employment conditions, peers and top management in the institutions generally feel less devoted to their work and become more exhausting, force them to leave the company and face high levels of pessimism and frustration. For this reason, the interest of experts and corporation executives is to study the process to boost employee happiness and deal with their psychological burnout and career development (Belias \& Koustelios, 2014).

Job happiness, which has an important positive effect on performance at work, indicates that the higher the level of opportunities available for learning at work leads to higher levels of energy that employees possess and they are then ultimately better at performing because they are recognized to attain the goals at work (Daniels \& Harris, 2000).

Happiness at job results in a positive attitude against the organizational work, which in turn causes to progressive achievement of corporate and performance objectives. This is the greatest advantage that a company could get by attaining the happiness of their employees. Workplace happiness means a workplace condition in which staff are happy to work but do not feel like they are burdened with work load, and are productive and accomplish focused goals, both at the staff and organizational level (Chaiprasit, 2011).

Hence, the modern day problem for employers is to identify ways to make and keep their workforce happy, as it is evident that happy and joyful employees are more productive for the organization and this is the issue this research attends to. Though there are studies which have been conducted on similar issues, no such work has been done in the context of Pakistani 
workplace to achieve happiness at work which can help employers understand the exact factors through which they can maintain the happiness level of their employees.

Understanding the importance of keeping employees happy and in search of avenues leading to this desired result, this study aims to discover whether career development, learning and work-life balance have a strong association and can lead to the happiness of employees working in Pakistani organizations.

\subsection{Gap Analysis}

This research aims to cover the gap and overcome the limitations that have been faced in previous studies on related topics that are the pillars of the current research, specifically of the base paper, which is the study conducted by (Joshanloo \& Jarden, 2016). The base paper, which forms the foundation of the current study, has focused on studying how hedonism directs to happiness in an individualistic culture over numerous nations of which some are developed, and some are under developed and are located in the various continents, like North America, Australia, Asia, etc.; which leaves room for focused analysis in any specific region. Moreover, the variables concentrated upon in (Joshanloo \& Jarden, 2016) are restricted to hedonism, happiness and individualistic culture only, and the results signify that individualism regulates the association between hedonism and happiness. The specific factors that may lead to happiness through hedonism were untouched by (Joshanloo \& Jarden, 2016) in his paper, like learning, work life balance and career development etc.

There have been many studies that have researched the variables in discussion in different context and in different geographical areas of the world. Several researches have also been performed in Pakistan that have studied some of the variables, but no study has focused on all the variables of this paper collectively in a single research, specifically in the Subcontinent, particularly Pakistan. Similar aspects of the work place have been examined in Pakistan (Jabeen \& Khan, 2016) to study the predictors of happiness for individuals in Pakistan. Nevertheless, in Pakistan, this sort of work is hardly pursued. The study analyzes the factors of personal happiness in Pakistan. Although their findings suggest that policy makers need to implement social programs to raise people's incomes and boost citizens ' health status to achieve the adequate amount of happiness for employees.

(Malik, Gomez, Ahmad, \& Saif, 2010) Has explored the impact of life-work flexibility and job satisfaction on workers' turnover intentions in Pakistan. Moreover, the key findings from the research concluded that the work-life balance has a significant positive association with job satisfaction and poor interaction with doctor's turnover plans. (Sohaib, Ihsaan, Yousaf, \& Majeed, 2015) Research aims to investigate the connection between learning factors and workplace learning, although their result culminates that there is significant positive linkage between individual learning and organizational support for learning.

(Saleem \& Amin, 2013) Studied the role of Human Resource department in Pakistan to enhance the knowledge, skills, and capabilities of their employees. Furthermore, the research was also focused upon recognizing the need and investigating the degree of its strength of employee career development and its important connection with organizational performance. 
Similarly, some papers have studied some of the variables of the current study in connection with others, for instance, career development has been studied with workforce development and retention in one study (Merchant Jr, 2010) which indicated career development has a significant long term impact on organizational performance, whereas in another research it has been studied along with structured organizational profession and job satisfaction, indicating a strong relationship with career development (Ismail, Adnan, \& Bakar, 2014) Likewise, work balance has been analyzed with working conditions and job satisfaction, proving that flexible working conditions and job satisfaction positively impact work life balance. (Aziz-Ur-Rehman \& Siddiqui, 2019) Work life balance has also been examined with emotional intelligence and the variables have been evidenced to be negatively proportionate to each other. (Gupta, 2014)Other researches have followed the similar trend of analyzing the different variables in this research in context of other elements, but not specifically together, hence, there was yet to be a research conducted that brought the variables of learning, career development and work life balance, on a single platform to study their impact on happiness through hedonism and this is the gap which the researcher has focused on closing through his study and has aimed to add to the already present literature on this topic by enhancing the awareness of how these variables, that is, learning, work life balance and career development effect happiness through hedonism in Pakistani workplace within the context of individualism (Hofstede Culture).

\subsection{Research Objectives}

The major objective and purpose of this research is to find the impact of work life balance, learning and career development at workplace on the happiness of an individual employee with hedonism mediating the impact. Furthermore, the impact is within the consideration of individualism (cultural dimension) and as discussed above, no empirical research has been conducted on these variables collectively in the Pakistani context. For such a reason, a large-scale analysis of literature in various research areas has been studied. In this work, the author's goal is also to learn the dark facts of related literature.

The work life balance of an employee is very important aspect of an individual's life as it is necessary to study its aspects on the happiness of an individual. Likewise, learning and career development are the factors that are considerably much important for a working individual, but it is the less noticeable factors at workplace, and how much it relates to happiness of an individual. While Hedonism is self-satisfaction and studying its effect on happiness with keeping in mind about the individualism/collectivisms aspect within an organization can't be ignored, for these reasons this research seems inevitable for knowing about the happiness of employees at their respective workplace, especially in Pakistan.

\subsection{Research Question}

The above mentioned problem statement and the gap identified in previous literature lead us to the following research questions which are made the focus of this current study:

To understand the impact of Individualism Cultural dimension of Hofstede on Happiness.

To understand the relation of Hedonism and Happiness. 


\section{Macrothink}

To understand the impact of work life balance, Learning and Career development on Hedonism.

\subsection{Significance}

This study contributes in the business/corporate sector fields respectively philosophically and functionally. At the same time, this research is useful of employees working in different organizations as they can evaluate their level of happiness linkage with the studied variables at workplace, while employer can overcome the problems that are linked with an individual's performance and can work on the betterment on workplace atmosphere by addressing the work life balance, learning and career development issues and by knowing how each factor is contributing to an individual's level of happiness. Additionally, by taking certain measures in the light of results, organizations can increase their productivity and can achieve their defined strategic objectives.

It will also be beneficial for the Government to regulate the better and effective working conditions rules within the organization in light of result of the study. Furthermore, it will help to evolve labor laws for the betterment of relation among employee and employer. Lastly, this study can be base for the future researchers and can provide them with great insights and factual information on the topic.

\section{Literature Review}

\subsection{Individualism (Dimension of Culture Hofstede)}

(Fujimoto \& Härtel, 2006) object of the study was to provide more knowledge on cross-cultural studies specifically in context of individualism vs collectivism and by knowledge of the study employer can enhance themselves for the betterment of workplace for which researchers interviewed different organizations as it was a qualitative research and evaluated the findings that results are influenced by collectivist intergroup biases and individualist relational perceptions monitored by the degree of culture-oriented HRM (Human Resource Management) policies and practices, and the sensitivity of individuals to bend-cultural experiences. When the workforce becomes homogeneous, organizations should customize HRM practices in order to make full use of the variety of skills and talents available from the diversity and to minimize the expense of affection and attitudes. As globalization and global competition continue to grow, organizations including those in the Asia-Pacific region should seriously reevaluate their HRM policies in order to adapt and benefit from an increasingly diverse workforce. The model provides a convenient foundation upon which scholars and members of organizations may construct their respective objectives.

Cross-cultural studies have shown that the most significant aspect of cultural differences throughout the globe's societies is the relative focus on individualism and collectivism (Hartel, Fujimoto, Strybosch, \& Fitzpatrick, 2006).

Culture represents the greatest effect on many individual behavioral aspects. The increasing prevalence makes it difficult to describe culture. (McCort \& Malhotra, 1993). (Wong, 2001) Focuses certain common theories about the "collectivism" Chinese job attitude. Based on studies from the P.R.C., Hong Kong, Taiwan and Singapore and contradicts it. And investigated whether the principle of Chinese Confucian collectivism, which prevails in the 
traditional Chinese family, still persists in today's organization of work. The controversial issue of collectivism is addressed on the basis of analyses of collectivism and individualism in Chinese-majority cultures, and consequences for possible collectivism and individualism research are also drawn. They were aimed to find either society of Chinese is individualistic or collectivistic \& in result they find there is still dominance of workplace towards collectivisms. In future this study will surely be help for researchers who eager to find factual information regarding Chinese culture.

(Yang et al., 2012) objective of the study was to differentiate the impact of workplace factors, work life balance in context of individualism among managerial level staff, for which they collected a large sample size which consist 6509 managers from 24 nations and tested by standard mechanism and revealed that, while workers from individualistic states served the same number of hours, they had a greater presumed workload in comparison with the people from collectivist countries. Furthermore, in comparison, associations with potential workload and bureaucratic limitations with task frustration and attrition expectations were more individualistic than they were in collectivist nations. Crucially, the findings of subsequent analyzes indicated that individualism-collectivism's cultural importance moderated the communication impact of perceived workload during work hours, and both workplace frustration and attrition intentions. They suggested to demonstrate the need to address current job stress concepts by introducing multi-level methods and integrating cross-national disparities in aspects such as individualism-collectivism. Moreover, this research will help the future researcher to develop a relationship among work life balance \& individualism-collectivisms.

(Man \& Lam, 2003) Basic concept of the study was to differentiate the level of stress at workplace with respect to individualism vs collectivisms. Furthermore, higher job sophistication and flexibility have often been correlated with better work group efficiency. This research explores the cohesiveness of the community as mediating influence.

Then there is testing of the balancing impacts of individualism/collectivism on the relationship among job qualities (both difficulty and autonomy) and consistency. The data set includes 381 teams taken from a global bank's divisions in Hong Kong and the U.S. The results suggest that an improvement in work difficulty and/or mission flexibility would enhance community cohesiveness, which converts into improved performance afterwards. Also, the potential benefits of task sophistication and individuality on workplace coherence was observed to be more common for individualistic workgroups rather than collectivist. Overall research has limitation of targeting only two nations. This study can be the ground for future researchers.

(Soares, Farhangmehr, \& Shoham, 2007) Had the basic purpose of study was to focus on Culture which is an enigmatic term and presents considerable challenges to cross-cultural research. It examines different attitudes in communication research to the conceptualization and operationalization of society. The article discusses the advantages about using cultural characteristics - especially the principles of Hofstede. The essay suggests a three-step method to operationalize culture through ethnicity, cultural aspects of Hofstede and individual level assessment of culture. This research will help to understand culture overall in terms of hosted dimensions and benefited the different marketers and also future researchers. 


\subsection{Learning}

(Littlejohn \& Margarayn, 2011) Examined the Learning behavior in the workplace in terms of collective or individual knowledge practices, in this paper they identified the set of different learning ways adapted by knowledge workers as the result of learning at work and analyzed how core information exchange activities are correlated with those learning practices: reading, communicating, generating and adding awareness. Learning method draws together a mixture of these elements to shape a distinct learning framework, offering a foundation for the rethinking of activities combined for more successful organizational learning and development. Quantitative survey method was adopted. This study demonstrates basic guidance into the interaction between organizational habits and attitudes of sharing knowledge and which variations of these in contrast of collective or individual knowledge practices can contribute to effective learning in the workplaces.

(Kyndt, Dochy, \& Nijs, 2009) Examine the existence of non-formal and informal occupational learning practices in regard to the attributes of the person and the company under which one works in. The developed questioner had 1162 employees from 31 different countries responses an observational component review was carried out to limit the number of variables and to search in the results for fundamental structures. Third, a set of variance analyzes were measured so that the variables could be contrasted in different types of employee classes. The study states that various types of workplace classes had varying chances of non-formal and informal learning for the five learning factors described in this study. The research concluded that one organization has Organizations have a connection to the existence of working environments or incentives for non-formal and informal learning in the workforce. Furthermore, this research only focuses on regular (permanent) employees.

(Manuti, Pastore, Scardigno, Giancaspro, \& Morciano, 2015) Investigated the role of learning process in career development and organization success. Moreover, the aim of this article was to examine the function of experience and knowledge as effective learning mechanisms that allow workplace skills to be learned and created. A business development planning approach has been developed to balance the corporate and employee roles involved in this process. To achieve so, the approach was to study the most recent literature on organizational learning, with a particular focus on its formal and informal aspects. The results showed significant positive effect among the relationship of learning with career development \& success of an organization that will be beneficial for the organizations to study. Researcher suggested future researcher to have study including some other variables too.

\subsection{Career Development}

(Merchant Jr, 2010) Research examined the Character and value of Career Development Plans in workforce development and retention. A Career Development Plan is designed to align the employee's interests with those of the employer with the main components being counselling and preparation. The study will explore the career development system and will concentrate on those methodologies that companies have effectively used in developing professional development initiatives. It would provide a structure from which the Altamonte Springs Police Department will develop a Career Development Program. Data on 100 police officers who retired from October 1983 to April 1995 is collected by interviews. After 
running different tests by running different test result suggested that career development program enhances organizational performance in long run furthermore employer empowerment is need of an hour for employee satisfaction. The research was limited to the one department future research can take it to next level.

(Ismail, Adnan, \& Bakar, 2014) Analysis to measure the association between structured organizational profession, expected career development assistance, and job satisfaction. The survey approach was used to obtain self-reported questionnaires from staff working in a higher learning institution focused on protection in Malaysia. The implications of the study of the Smart PLS route model revealed two interesting findings: first, the association between career planning and career management was highly correlated with job satisfaction and was meaningful. Further, the association regarding perceived encouragement for career development was favorably and closely associated with job satisfaction. This result indicates that expected career development assistance serves as a major mediating factor in the connection among programmed workplace role and job satisfaction in the organizational study. Future researcher can do work to the remaining related aspects such as career performance, job stress, trust, and ethics.

(Kaya \& Ceylan, 2014) Examined the Career development initiatives in companies and corporate contribution to job satisfaction for workers are analyzed, and their role in that job satisfaction. A survey is conducted within a sample group that works in different industries. A questionnaire is being prepared at this point which consists of two parts of 43 questions rated on the7-point Likert attitude scale. The study was conducted on 204 employees who work in various sectors. In the study, the data acquired from the assessment of the survey results were described using the software program SPSS statistics. The findings of the assessment imply that career development projects and organizational commitment have a limited effect on the job satisfaction of employees, organizational commitment has a direct as well as positive impact on job satisfaction, and career development programs in organizations may not impact the job satisfaction level of staff. The study is useful for managers at different corporates.

\subsection{Work Life Balance}

(Aziz-Ur-Rehman \& Siddiqui, 2019) Studied the interaction between flexible work conditions, work-life balance and job satisfaction at universities in the Karachi public sector. The aim of this study is to investigate the null hypothesis that there is no connection around flexible work structures, work-life balance and job satisfaction of Karachi employees at public universities. The research was methodology was a mix of both, adopted questioner as research tool it were distributed by random sampling technique at different public universities of Karachi and also filled by online targeted. The results show that flexible conditions are associated strongly and substantially with work-life balance. The research also showed that work-life balance between flexible working conditions and job satisfaction is a good mediator. The study has certain limitations such as used convenience sampling and limited to a single City.

(Azara, Khana, \& Van Eerdeb, 2018) Has cited in their research that conversely, work-life conflict and work-family conflict were found, although the nature of the former was narrower than the latter. The work-life conflict has been considered to be more accurate term than 
work-family conflict, as workers without family and family care commitments are also subject to the conflict among positions in the realms of work versus non-work; non-work domains can include friends and free time.

(Gupta, 2014) examined the role of Emotional Intelligence in handling job disputes and improving the quality of work life and IT professionals ' satisfaction so that employee can be productive for the organization. Data collection were qualitative in which different randomly selected it workers from Goa were selected for an interview and by going through different tests it has been observed that major reason due to which employee seeking to quit their jobs is work life balance.

Even when it comes to sexuality, there is less link between flexible work structures and disputes between work and life. Evidence has shown that working from home contributes to more problems with the work families (Chung \& Van der Lippe, 2018).

According to (Greenhaus, Collins, \& Shaw, 2003), Work-life balance represents the constructive engagement of a person to multiple roles, a concept of inter-roles. He indicated that people should be balanced in their lives in various roles, and balance applies to a fulfilling, happy, and productive life that involves job, recreation, and affection, etc.

\subsection{Hedonism}

(Veenhoven, 2003) Studied that Hedonism is a way of life marked by responsiveness to the sense of enjoyment. There's a lot of trouble about hedonism. It is socially opposed and said to be counterproductive to long-term satisfaction. Many explanations have been proposed for this' paradox of hedonism' and troubling accounts have been provided of gratification seekers going to end up in desperation. This paper provides an overview of whether this is the norm and if so, where is too much pleasure. The connection between hedonism and pleasure was analyzed on two concentrations: nations and individuals. An average satisfaction at the national level is associated with social tolerance of luxury and productive leisure. It is also associated to hedonistic beliefs at the individual level, and also correlates with hedonistic habits such as frequent sex and sedative usage. The trend is usually linearly optimistic. The relationship between happiness and stimulant intake follows an inverted U-curve, spoilsports and sippers are less pleased than modest end users. Nevertheless, such results cannot solve the problem, as the interactions identified may be false or, instead of the opposite, due to the effects of pleasure on hedonism. Although we can demonstrate a beneficial effect of (mild) hedonism on happiness, the question remains how that benefits sustain against several potential health loss. One solution is to evaluate the impact of hedonistic living on gladly lived years.

(Joshanloo \& Jarden, 2016) Hypothesize that in more individualistic (vs. collectivist) society's hedonism (appraising pleasure) as a road to satisfaction is more closely correlated with happiness. Dual-level modeling is being used to test the theory in a study of 6899 entities across 19 cultures, governing for age, sexuality, and global economic wealth. As expected, individualism moderates the relationship between hedonism and happiness, so that hedonism in much more individualistic cultures is more closely related to happiness. Such findings suggest that religion affects how pleasure is achieved more successfully in different cultures. 
(Joo \& Lee, 2017) Studied the employee engagement or health is an important subject in both psychology and management. The aim of this paper is to examine the impact of presumed institutional support (POS) and psychological resources (PsyCap) on employee productivity (i.e. job engagement), employment success (i.e. career fulfillment), and life (i.e. subjective well-being (SWB) at workplace. Information is gathered from 550 workers in a South Korean company. We performed confirmatory factor analysis, reliability and association research, and simulation of structural equations for statistical analysis. It even discovered that organization feature has a strong effect on workplace happiness and well-being hedonism of an individual than of national culture.

\subsection{Happiness}

(Al-Ali, Ameen, Isaac, Khalifa, \& Shibami, 2019) Examine the mediating effect of job happiness variable on the connection between job satisfaction and the overall quality and turnover of workers. Questionnaires were collected that revealed the job satisfaction indicator has a major direct positive correlation with both job performance and work enjoyment indicators while it has an insignificant negative correlation with the attrition plan of workers. At the other hand, the career happiness has a significant positive direct effect on job performance, but it does record a serious negative effect on the intention of employee turnover.

(Adnan Bataineh, 2019) aims to examine the Relation of Joy (happiness) along with Work Life Balance, and Employee satisfaction. Therefore, a questionnaire-based survey was designed to test the above hypothesis based on data set of 289 employees from the (Med Pharma), Pharmaceutical Industries in Jordan, Multiple regression was conducted to analyze the research theories. The findings showed that work life balance and enjoyment impacted workplace efficiency favorably and substantially. Furthermore, work happiness does not affect the performance of the employee. The findings have a huge useful impact on Jordan's pharmaceutical industry for present and future.

(Fan \& Smith, 2017) Investigated that failure to maintain railway workers' well-being and work-life balance will lead to a higher danger to train safety and the welfare of employees. The article reports the findings of a study that quantified positive well-being and work-life balance and recognized the factors that affected railway personnel in the UK. Generally, workers who experienced high levels of control and encouragement had a better work-life balance and a greater sense of wellbeing. A good attitude has been related to improved well-being both at work and outside the workplace.

\section{Theoretical Framework}

\subsection{Happiness}

If asked to think about happiness, several people think of their personal achievements and other positive experiences in line with the good experiences. Happiness is typically defined as 'a state of well-being characterized by relative permanence, predominantly pleasant emotions ranging from mere contentment to deep and intense joy in life, and a natural desire for continuation'. Psychological research on happiness, in conformance with this definition, has focused on the long-term emotional state of happiness of an individual and the positive 
evaluation of one's life. In other terms, a good person is a person who at the same time has enjoyable emotions and is content with his or her overall life (Oishi \& Gilbert, 2016).

Happiness may be common as a frame of mind, but its nature is nuanced and unclear. ( $\mathrm{Lu}$, Gilmour, \& Kao, 2001) This is the rule of thumb among the people of this world that day value the most to their pleasure which can be e range from physical sensation to emotional observations in a pleasant way (Higgins, 1997).

Subjective wellbeing (or more colloquially, happiness) is generally sought by people around the world. (Boehm, Lyubomirsky, \& Sheldon, 2011) And their actions to achieve it are driven by motivations such as the desire for integrity, relation, fairness and information for which enjoyment can be deferred or abandoned (Higgins, 1997).

\subsection{Hedonism}

The word ' hedonism ' is used in several ways. It reflects the belief, across moral philosophy, that a better life should be a satisfying one. It accounts for the theory in psychology that finding pleasure is a huge motivator in human behavior. Concisely Hedonism is about valuing pleasure.

According to (Veenhoven, 2003) the merits of this hedonism are a longstanding discussion.

Some are celebrating it as healthy and natural, but others are contrasting hedonism with overconsumption and moral decline. The mixed hedonic sentiments are mirrored in the connotations encircling the word. On first-hand hedonism is associated with great taste and the art of residing well; but on the other side, it is correlated with addiction, superficiality, reckless behavior and short-sighted selfishness.

The willingness to participate in demanding and arduous activities and tasks in the pursuit of long-term goals has been regarded as a significant intermediary of overall success and quite well-being (Schmeichel, Vohs, \& Baumeister, 2003). Therefore, gratification is obviously attractive, but it may need to be deferred or forsaken regularly to promote persistent target-driven behavior. Hedonism is prioritized variably in different types of cultures.

Human nature always tends to seek comfort and pleasure either it is their personal live or professional live whereas there have been various researches in the past to evaluate the criteria of achieving maximum happiness and satisfaction of a person.

$\mathrm{H} 1$ : There is a significant positive relationship between employee hedonism and happiness.

Pleasure (Hedonism) and happiness are dependent on various variables through which it is attained, of which some can be quantified while others cannot be measured in a quantitative manner. Achieving the maximum level of pleasure simply just couldn't energize the human instinct and extinct behavior. A certain search confirms that humans can value unpleasant emotions in comparison to pleasure emotions/ unpleasant emotions when those emotions seem more useful for that particular situation (Tamir \& Mauss, 2011).

Therefore, people often have to dampen their natural inclination to optimize enjoyment and relaxation in order to achieve long-term goals (Baumeisteer, 2005).

\subsection{Career Development}

From a career perspective, this survey explored the relationship between success and 
happiness, especially in terms of the moderators of these buildings. Career success requires two dimensions (objective and subjective job progress) and the corresponding moderators have also been checked.

(Pan \& Zhou, 2013) Indicated that the importance of career success (internal quality) moderates the relationship between pay and happiness, and work dedication regulates the relationship among career satisfaction and happiness.

H2: There is a significant positive relationship between employee Career Development and hedonism.

A good career option is one that provides opportunities to develop, sustain energy and dedication, work-life balance and satisfaction. The results reflected that career development prospects in an organization positively effects work life balance of an individual working in the organization along with increasing ones satisfaction, positivity which overall increase satisfaction of each employees (DeCenzo, Robbins, \& Verhulst, 2016).

\subsection{Work-Life Balance}

Work life balance refers to a condition of balance under which the demands of the personal and professional lives of both of an individual are equivalent. According to (Lockwood, 2003) work life balance is the key moderator for reducing absenteeism and increase productivity at work.

H3: There is a significant positive relationship between employee work life balance and hedonism.

Work-life value refers to the level of happiness or dissatisfaction with one's career It is said that those who enjoy their careers have a high quality of working life, while those who are unhappy or whose needs are otherwise unfulfilled are said to have low quality of working life. Work-life quality is seen as an alternative to managing people's control approach. (Balaji, 2016).

Level of happiness has some relationship with work life balance. Proposed changes in the composition of the employees apply to the work-life balance framework (Karkoulian, Srour, \& Sinan, 2016).

Unless one partner works in the afternoon, the couple could not allow social events take place during such workdays to enter the evening. Particularly when wives work at night, families often could not even eat their meal together or relish time with the family around each other (Chait Barnett, Gareis, \& Brennan, 2008).

Therefore, regulation of impactful happiness at workplace may serve as a process through which individuals attain their ideal work life and ultimately lead to lower levels of stress (Johnston, Luciano, Maggiori, Ruch, \& Rossier, 2013).

\subsection{Employee Learning}

Learning at workplace define as the work-related knowledge and increase in that pool timely and efficiently. Although various research has been done to understand the concept of the linkage among learning of an individual at their respective working environment with his/her happiness at the place of working. The relation among learning and happiness cannot be 
neglected.

According to (Kyndt, Dochy, \& Nijs, 2009) Organizations should promote non-formal and informal learning across tradition, policies and individual activities by proper adoption and mediation of culture.

Learning is an integral part of an individual life, over the years there have been many attempts to define the field of organizational learning and it is not possible here to give a comprehensive review (Knoke, 2018).

H4: There is a significant positive relationship between employee learning and hedonism.

According to (Lundvall, Rasmussen, \& Lorenz, 2008) Knowledge constitutes a significant source of strategic advantage for businesses. Furthermore, in order to gain access and then use the best attributes of learning anywhere they live in the world, workers must be capable of working together in communities, networks and with the public.

\subsection{Individualism (Hofstede Culture)}

Individualistic societies put special emphasis on personal interests over group objectives and promote the presentation of one's individual values, behaviors, and desires. In affirming the importance of the private self in these societies, emotional satisfaction and positive emotions are critical (Kitayama \& Markus, 2000). It has been observed that individualistic cultures esteem happiness more than collectivistic cultures (Schwartz, 2009).

Examples of parenting styles across societies suggest that parents in collectivistic cultures give their children greater priority in fostering self-discipline and enhancing influence (Baumeister \& Tierney, 2011).

Although in individualistic cultures possessing commitments and opinions for others can be called a limitation (Schwartz, 2015) or a "drag on having fun", social cultures prioritize community unity over self-interests and pleasures. (Joshanloo \& Jarden, 2016).

According (Joshanloo M. , 2014) to such societies tend to view well-being as primarily comprising of conventional values (such as selflessness and harmony), which are less in line with the hedonistic mindset.

H5: There is a relationship between Individualism Culture with happiness.

The core theme of emerging theories of social development was the distinction between individual and collective attitude, and hence between different sources of happiness (Valente \& Berry, 2015).

In summary, it appears that individualistic cultures regard enjoyment as a more central component of wellbeing than collectivistic cultures. Humans seem to add equal or greater significance in collectivistic societies without social unity, values and ideals other than fun. Therefore, we expected that in individualistic nations, the connection between hedonism and pleasure would be greater than in collectivistic nations.

A large body of research confirms this hypothesis, demonstrating that a congruence between the beliefs of individuals and the principles stressed in their cultural environment is important for psychological well-being (Sagiv, Roccas, \& Oppenheim-Weller, 2015).

In other terms, because hedonism is more in accordance with the cultural norms that exist in 


\section{Macrothink}

Human Resource Research

ISSN 1948-5441 2020, Vol. 4, No. 1

individualistic societies, we thought that in these cultures it would be more closely related to pleasure.

Individualism-collectivism describes rising culture's relationships. People often provide for themselves and their immediate family in individualistic communities while people belong to associations in collectivistic cultures who look after them in return for allegiance.

H6: Individualism Culture has an impact on the relationship between hedonism and happiness.

In brief According to (Sagiv, Roccas, \& Oppenheim-Weller, 2015), individualistic societies have seemed to perceive satisfaction as a more important element of well-being than collectivist societies. Persons of collectivist cultures, such as group unity, seem to give equal or greater significance to values and ideals apart from enjoyment. So, we expected that in individualistic states the connection between hedonism and pleasure would be greater relative to collectivist states. This hypothesis is confirmed by a wide range of research that shows that a reflexivity between the ideals of individuals and those stressed in their cultural environment is important for psychological well-being. Shown in below Figure 1.

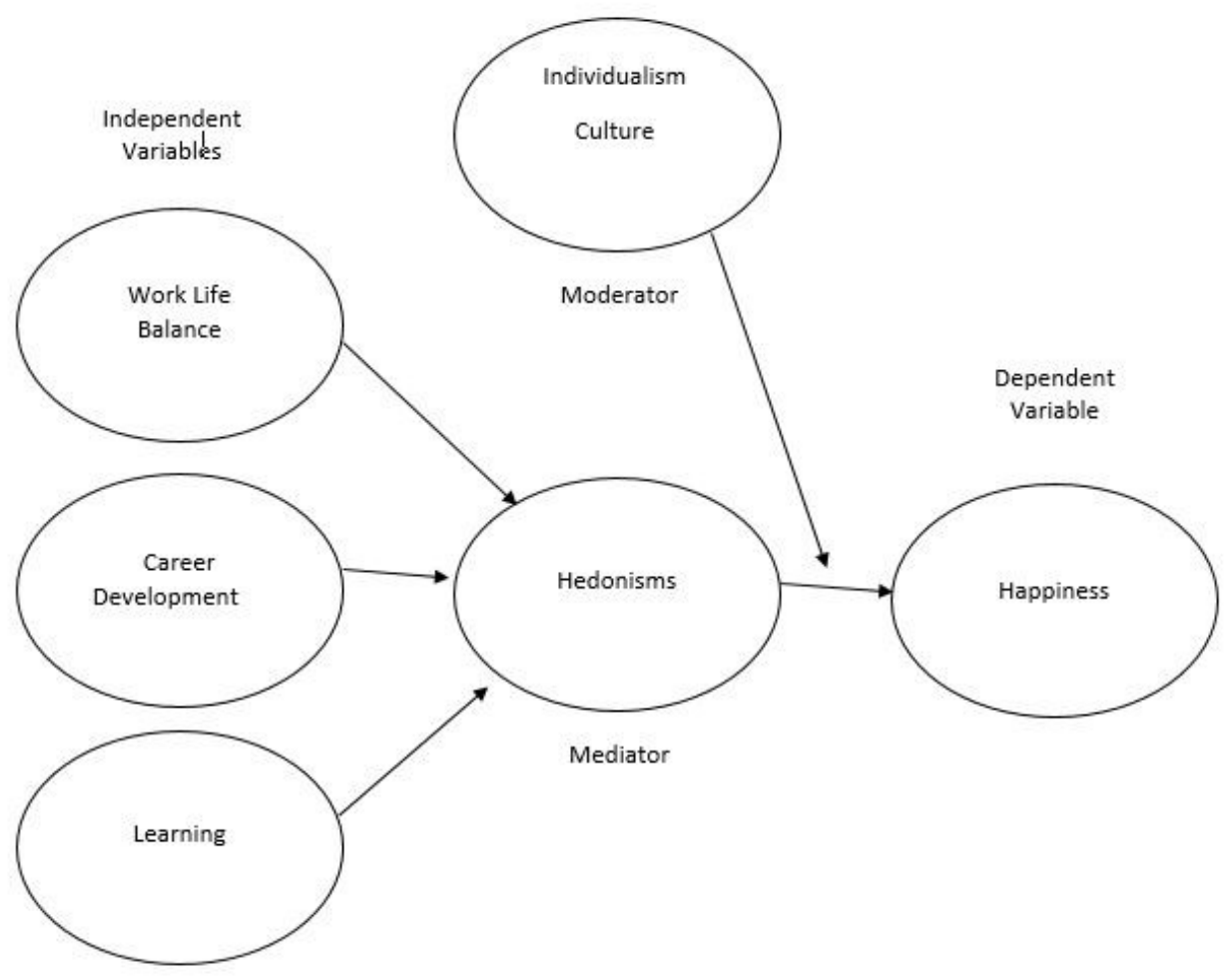

Figure 1. Research model

The above model lays down the theoretical framework for this research which studies the relationship of each of the independent variables, namely, work life balance, career development and learning with happiness as the dependent variable. Hedonism is used as a variable to mediate the relationship of each of the independent variables with happiness; and culture plays the role of a moderator to test the strength of the relationship of each of the predictors with the criterion variable respectively. Overall the research is comprised of seven 


\section{Macrothink}

factors which are further discussed in detail in the various parts of our research paper.

\section{Methodology}

\subsection{Questionnaire Design}

Questionnaire has been chosen as the adopted instrument for primary data collection which comprised of 42 questions altogether which were followed by some demographic questions like the name of the organization the respondents were working in, age, marital status, working experience, and the department of persona works and the sector of that particular job. The overall question there were five questions from individualism dimension of culture, five from work-life balance, 5 from career development, 5 from learning, 18 from hedonism and four from happiness.

The Subjective Happiness (Joshanloo \& Jarden, 2016) Scale from (Lyubomirsky \& Lepper, 1999) uses to quantify the happiness via scale that ranges from less happy to more happy on the values ranging from 1-7. The Cronbach's alpha of the scale is 0.482 . The scale for rest of the variable was Likert which were ranging from 1-5 and had choices ranging from strongly disagree, disagree, neutral, agree \& strongly agree. The CB Alpha of Hedonism, Career Development, Work life balance, learning, individualism are $0.066,0.798,0.559,0.828 \&$ 0.705 respectively.

The enjoyment (Hedonism) subscale of the Instructions to Happiness was adopted from (Seligman, Steen, Park, \& Peterson, 2005) which quantifies the Hedonistic way of living. This scale tests the extent by which participants appreciate emotional and physical joy in life, and finds it a road to happiness, which has total of 18 questions and we adopted it as it is.

According to (Triandis \& Gelfland, 1998). Level of individualism and collectivism (also known as level of culture-orientation) conceptualize that people from various societies have distinctly different constructions of themselves, others, and the interconnectedness of the 2 . Such frameworks can impact, and often define, the very existence of individual experiences, including awareness, attitude, and motivation the scale will calculate the society individualism vs collectivisms factor.

The questionnaire was developed by (Otken \& Erben, 2013). Currently, several organizations are applying organizational measures and human resource tools to help their workers decrease the above-mentioned conflicts and balance work and the domain of life.

The questionnaire on career development were adopted from (Akkermans, Brenninkmeijer, Huibers, \& Blonk, 2013). Furthermore, this research intended to contribute by incorporating the literature available and by establishing and empirically evaluating the Career enhancement chances at workplace.

(Akkermans, Paradniké, Van der Heijden, \& De Vos, 2018). The study Stress the importance of fostering student engagement. Getting involved in learning events, the questionnaire had Likert scale and was adopted as it is.

\subsection{Sample}

In research, the sample size which we collected was from different resources and different organizations located in the city of Karachi. We collected data from 219 participants. Table 1 shows the details of each respondent's demographics which reflects the input of different 


\section{Macrothink}

Human Resource Research

ISSN 1948-5441 2020, Vol. 4, No. 1

people in this research regardless of any type of discrimination or limitation to a certain extent.

Table 1. Data analysis Composition of Data $(n=219)$

\begin{tabular}{|c|c|c|}
\hline & Frequency & Percent \\
\hline \multicolumn{3}{|l|}{ Gender } \\
\hline Males & 145 & 66.2 \\
\hline Female & 74 & 33.7 \\
\hline \multicolumn{3}{|l|}{ Age } \\
\hline $21-30$ & 178 & 81.2 \\
\hline $31-40$ & 25 & 11.4 \\
\hline $41-50$ & 08 & 3.65 \\
\hline $51-60$ & 06 & 2.73 \\
\hline Above 60 & 02 & 0.09 \\
\hline \multicolumn{3}{|l|}{ Experience } \\
\hline Less than a Year & 27 & 12.3 \\
\hline $1-5$ Years & 145 & 66.2 \\
\hline 6-10 Years & 23 & 10.5 \\
\hline 11-15 Years & 15 & 6.84 \\
\hline Above-16 & 9 & 4.10 \\
\hline \multicolumn{3}{|l|}{ Education Level } \\
\hline Graduate & 132 & 60.2 \\
\hline Post Graduate & 86 & 39.2 \\
\hline PHD & 1 & 0.45 \\
\hline \multicolumn{3}{|l|}{ Marital Status } \\
\hline Single & 162 & 73.9 \\
\hline Married & 50 & 22.83 \\
\hline Divorced & 07 & 3.19 \\
\hline \multicolumn{3}{|l|}{ Sector } \\
\hline Private & 206 & 94.06 \\
\hline Public & 11 & 5.02 \\
\hline Semi Private & 02 & 0.91 \\
\hline
\end{tabular}


HR

IT

Finance

Marketing

Administration

SCM

In Table 1. Data we gather have a total of 145 male and 74 female which makes the ratio of 80:20 approximately. The most common age group we had in our research work was from the age bracket of 21 to 30 , which is more than $80 \%$ of our total population. Mostly people have 1 to 5 years of professional experience and most of them were at the educational level of being a graduate. Majority of the respondents were single and working in private organizations and there is a mix ratio of people working in different departments, but the most prominent one department was of marketing, then HR and followed by finance. All instruments and their sources are mentioned as follow in Table 2 .

Table 2. Descriptive statistic

\begin{tabular}{|c|c|c|c|c|c|c|c|}
\hline \multirow{2}{*}{ Variables and Factors } & \multirow{2}{*}{ Source } & \multirow{2}{*}{ uestions } & \multicolumn{2}{|c|}{$\begin{array}{l}\text { Descriptive } \\
\text { Stats }\end{array}$} & \multicolumn{2}{|c|}{$\begin{array}{l}\text { Confirmatory } \\
\text { Analysis }\end{array}$} & \multirow{2}{*}{$\begin{array}{l}\text { Factor } \\
\mathrm{P} \\
\text { Values }\end{array}$} \\
\hline & & & Mean & $\begin{array}{l}\text { Standard } \\
\text { deviation }\end{array}$ & $\begin{array}{l}\text { Outer } \\
\text { Loading }\end{array}$ & T Stats & \\
\hline $\begin{array}{l}\text { Human Happiness } \\
\text { Factor }\end{array}$ & $\begin{array}{l}\text { (Joshanloo \& } \\
\text { Jarden, 2016) }\end{array}$ & $\begin{array}{l}\text { In general, } \\
\text { consider } \\
\text { myself: }\end{array}$ & I 5.35 & 3.61 & 0.567 & 14.225 & 0.000 \\
\hline $\begin{array}{l}\text { Human } \\
\text { Factor Happiness }\end{array}$ & $\begin{array}{l}\text { (Joshanloo \& } 2 \\
\text { Jarden, 2016) }\end{array}$ & $\begin{array}{l}\text { Compared } \\
\text { most of } \\
\text { peers, } \\
\text { consider } \\
\text { myself: }\end{array}$ & $\begin{array}{ll}\text { o } & \\
\text { y } & \\
\text { I } & \\
& 5.30\end{array}$ & 3.42 & 0.469 & 9.422 & 0.000 \\
\hline
\end{tabular}




\begin{tabular}{|c|c|c|c|c|c|c|c|c|}
\hline $\begin{array}{l}\text { Human } \\
\text { Factor }\end{array}$ & Happiness & $\begin{array}{l}\text { (Joshanloo \& } \\
\text { Jarden, 2016) }\end{array}$ & $\begin{array}{l}\text { Some people } \\
\text { are generally } \\
\text { very happy. } \\
\text { They enjoy life } \\
\text { regardless of } \\
\text { what is going } \\
\text { on, getting the } \\
\text { most out of } \\
\text { everything. To } \\
\text { what extent } \\
\text { does this } \\
\text { characterization } \\
\text { describe you? }\end{array}$ & 4.89 & 2.07 & 0.871 & 21.536 & 0.000 \\
\hline $\begin{array}{l}\text { Human } \\
\text { Factor }\end{array}$ & Happiness & $\begin{array}{l}\text { (Joshanloo \& } 4 \\
\text { Jarden, 2016) }\end{array}$ & $\begin{array}{l}\text { Some people } \\
\text { are generally } \\
\text { not very happy. } \\
\text { Although they } \\
\text { are not } \\
\text { depressed, they } \\
\text { never seem as } \\
\text { happy as they } \\
\text { might be. To } \\
\text { what extend } \\
\text { does this } \\
\text { characterization } \\
\text { describe you? }\end{array}$ & 3.79 & 0.12 & -0.361 & 3.870 & 0.000 \\
\hline Culture & Individualism & $\begin{array}{l}\text { (Triandis \& } 5 \\
\text { Gelfland, 1998) }\end{array}$ & $\begin{array}{lr}\text { I'd } & \text { rather } \\
\text { depend } & \text { on } \\
\text { myself } & \text { than } \\
\text { others. } & \end{array}$ & 4.15 & 0.49 & 0.386 & 10.637 & 0.000 \\
\hline Culture & Individualism & $\begin{array}{l}\text { (Triandis \& } 6 \\
\text { Gelfland, 1998) }\end{array}$ & $\begin{array}{l}\text { I rely on myself } \\
\text { most of the } \\
\text { time; I rarely } \\
\text { rely on others. }\end{array}$ & 3.74 & 0.08 & 0.351 & 8.819 & 0.000 \\
\hline Culture & Individualism & $\begin{array}{l}\text { (Triandis \& } 7 \\
\text { Gelfland, 1998) }\end{array}$ & $\begin{array}{l}\text { I often do "my } \\
\text { own things. }\end{array}$ & 3.92 & 0.22 & 0.824 & 18.057 & 0.000 \\
\hline
\end{tabular}




\begin{tabular}{|c|c|c|c|c|c|c|c|c|}
\hline Culture & Individualism & $\begin{array}{l}\text { (Triandis \& } \\
\text { Gelfland, 1998) }\end{array}$ & 8 & $\begin{array}{l}\text { My personal } \\
\text { identity, } \\
\text { independent of } \\
\text { others, is very } \\
\text { important to } \\
\text { me. }\end{array}$ & 0.32 & 0.784 & 11.665 & 0.000 \\
\hline Culture & Individualism & $\begin{array}{l}\text { (Triandis \& } \\
\text { Gelfland, 1998) }\end{array}$ & 9 & $\begin{array}{l}\text { It is important } \\
\text { that I do my job } 4.00 \\
\text { better than } \\
\text { others. }\end{array}$ & 0.30 & 0.440 & 4.856 & 0.000 \\
\hline $\begin{array}{l}\text { Personal } \\
\text { Interest }\end{array}$ & $\begin{array}{l}\text { Work } \\
\text { Balance }\end{array}$ & $\begin{array}{l}\text { (Otken \& } \\
\text { Erben, 2013) }\end{array}$ & 10 & $\begin{array}{l}\text { Job gives me } \\
\text { energy to } 2.47 \\
\text { pursue personal } \\
\text { activities. }\end{array}$ & 0.96 & 0.193 & 0.834 & 0.405 \\
\hline $\begin{array}{l}\text { Personal } \\
\text { Interest }\end{array}$ & $\begin{array}{l}\text { Work } \\
\text { Balance }\end{array}$ & $\begin{array}{l}\text { (Otken \& } \\
\text { Erben, 2013) }\end{array}$ & 11 & $\begin{array}{l}\text { Personal life } \\
\text { suffers because } 2.45 \\
\text { of work. }\end{array}$ & 1.00 & 0.849 & 1.932 & 0.054 \\
\hline $\begin{array}{l}\text { Personal } \\
\text { Interest }\end{array}$ & $\begin{array}{l}\text { Work life } \\
\text { Balance }\end{array}$ & $\begin{array}{l}\text { (Otken \& } \\
\text { Erben, 2013) }\end{array}$ & 12 & $\begin{array}{ll}\text { Job } & \text { makes } \\
\text { personal } & \text { life } 3.07 \\
\text { difficult. } & \end{array}$ & 0.14 & 0.291 & 2.053 & 0.041 \\
\hline $\begin{array}{l}\text { Personal } \\
\text { Interest }\end{array}$ & $\begin{array}{l}\text { Work } \\
\text { Balance }\end{array}$ & $\begin{array}{l}\text { (Otken \& } \\
\text { Erben, 2013) }\end{array}$ & 13 & $\begin{array}{l}\text { I miss Personal } \\
\text { activities } \\
\text { because of } 2.66 \\
\text { work. }\end{array}$ & 0.63 & 0.262 & 2.071 & 0.039 \\
\hline $\begin{array}{l}\text { Personal } \\
\text { Interest }\end{array}$ & $\begin{array}{ll}\text { Work life } \\
\text { Balance }\end{array}$ & $\begin{array}{l}\text { (Otken \& } \\
\text { Erben, 2013) }\end{array}$ & 14 & $\begin{array}{l}\text { Hard to work } \\
\text { because of my } 3.13 \\
\text { personal } \\
\text { matters. }\end{array}$ & 0.10 & 0.585 & 1.833 & 0.067 \\
\hline $\begin{array}{l}\text { Personal } \\
\text { Growth }\end{array}$ & $\begin{array}{l}\text { Career } \\
\text { Development }\end{array}$ & $\begin{array}{l}\text { (Akkermans, } \\
\text { Brenninkmeijer, } \\
\text { Huibers, \& } \\
\text { Blonk, 2013) }\end{array}$ & 15 & $\begin{array}{l}\text { I know what is } \\
\text { important to me } 3.99 \\
\text { in my career. }\end{array}$ & 0.29 & 0.836 & 10.384 & 0.000 \\
\hline $\begin{array}{l}\text { Personal } \\
\text { Growth }\end{array}$ & $\begin{array}{l}\text { Career } \\
\text { Development }\end{array}$ & $\begin{array}{l}\text { (Akkermans, } \\
\text { Brenninkmeijer, } \\
\text { Huibers, \& } \\
\text { Blonk, 2013) }\end{array}$ & 16 & $\begin{array}{l}\text { I can clearly } \\
\text { see what my } \\
\text { passions are in } \\
\text { my work. }\end{array}$ & 0.15 & 0.576 & 8.072 & 0.000 \\
\hline $\begin{array}{l}\text { Personal } \\
\text { Growth }\end{array}$ & $\begin{array}{l}\text { Career } \\
\text { Development }\end{array}$ & $\begin{array}{l}\text { (Akkermans, } \\
\text { Brenninkmeijer, } \\
\text { Huibers, \& } \\
\text { Blonk, 2013) }\end{array}$ & 17 & $\begin{array}{l}\text { I can make } \\
\text { clear } \quad \text { career } 3.55 \\
\text { plans. }\end{array}$ & 0.01 & 0.278 & 7.883 & 0.000 \\
\hline
\end{tabular}




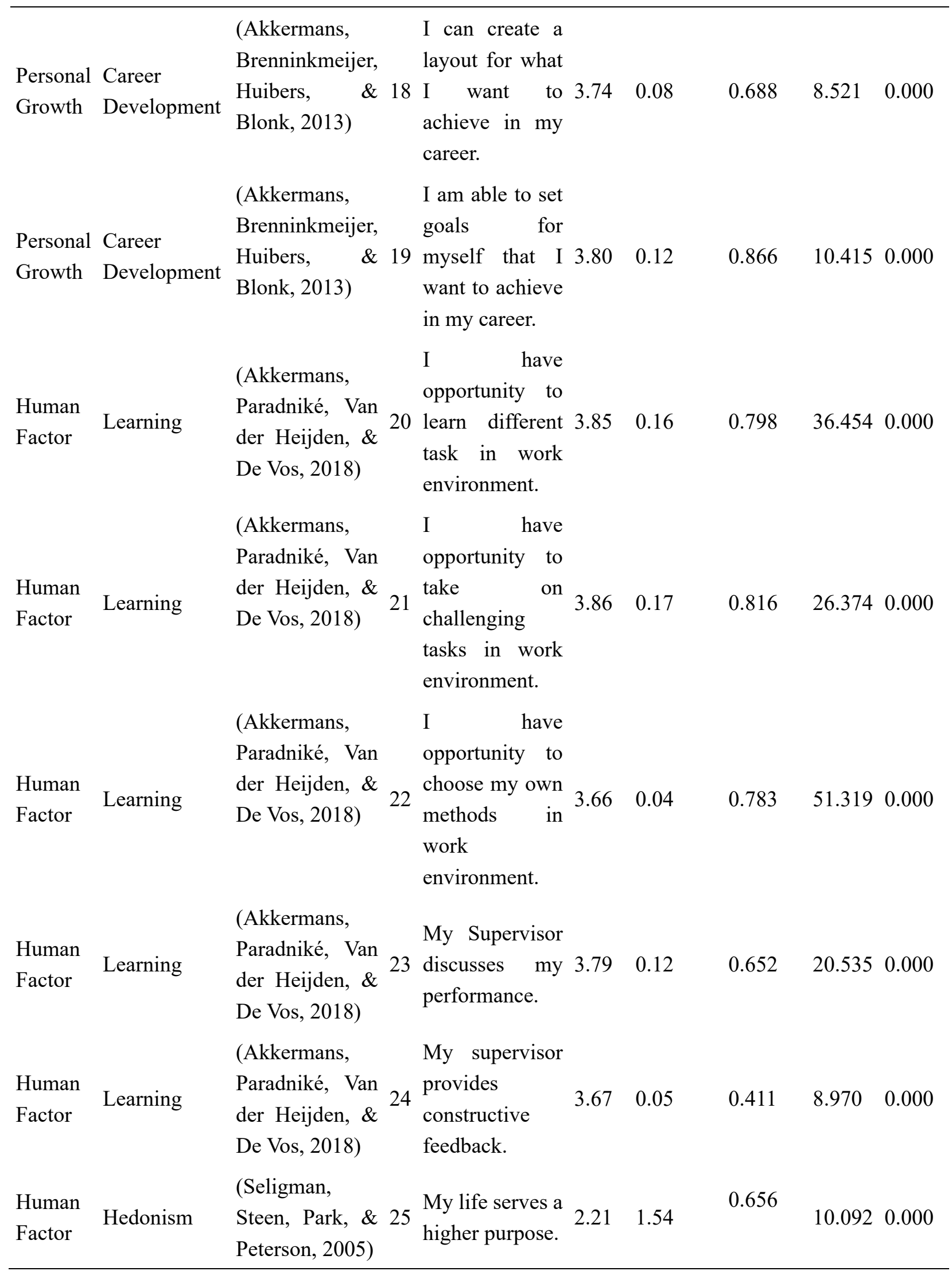


Human Hedonism

Factor

Human

Factor

Human

Factor

Human

Factor

Human

Factor

Human

Factor

Human

Factor

Hedonism

Hedonism

Steen, Park, \& 29 matters
Peterson, 2005)

(Seligman,

Steen, Park, \& responsibility

Peterson, 2005) 27 to make the 2.231 .49

world a better

place.

(Seligman,

My life has a

Steen, Park, \& 28 lasting

Peterson, 2005)

(Seligman, What I do

(Seligman,

Steen, Park, \&

Peterson, 2005)

and how I fit

(Seligman,

Steen, Park, \&

Hedonism

Peterson, 2005)

31

(Seligman,

Hedonism

Steen, Park, \& 32

Peterson, 2005)

(Seligman,

Steen, Park, \&

Human

Factor
Hedonism
Peterson, 2005)

33 meaning.

I have spent a

lot of time

what life means 2

into its big

picture.

Life is too

short to

pleasures it can

provide.

I go out of my

euphoric.

In choosing

$\begin{array}{lllll}2.40 & 1.10 & 0.375 & 5.425 & 0.000\end{array}$

what to do, I

into take

whether it will

$\begin{array}{lllll}3.72 & 0.07 & -0.401 & 5.452 & 0.000\end{array}$

be pleasurable. 


\begin{tabular}{|c|c|c|c|c|c|c|c|}
\hline $\begin{array}{l}\text { Human } \\
\text { Factor }\end{array}$ & Hedonism & $\begin{array}{l}\text { (Seligman, } \\
\text { Steen, Park, \& } \\
\text { Peterson, 2005) } 34\end{array}$ & $\begin{array}{l}\text { I agree with this } \\
\text { statement: } \\
\text { "Life is short }-3.36 \\
\text { eat dessert } \\
\text { first." }\end{array}$ & 0.01 & 0.725 & 4.586 & 0.000 \\
\hline $\begin{array}{l}\text { Human } \\
\text { Factor }\end{array}$ & Hedonism & $\begin{array}{l}\text { (Seligman, } \\
\text { Steen, Park, \& } 35 \\
\text { Peterson, 2005) }\end{array}$ & $\begin{array}{l}\text { I love to do } \\
\text { things } \\
\text { excite that } \\
\text { senses. }\end{array}$ & 0.26 & -0.274 & 14.224 & 0.000 \\
\hline $\begin{array}{l}\text { Human } \\
\text { Factor }\end{array}$ & Hedonism & $\begin{array}{l}\text { (Seligman, } \\
\text { Steen, Park, \& } 36 \\
\text { Peterson, 2005) }\end{array}$ & $\begin{array}{l}\text { For me, the } \\
\text { good life is the } 3.81 \\
\text { pleasurable life. }\end{array}$ & 0.13 & -0.567 & 5.059 & 0.000 \\
\hline $\begin{array}{l}\text { Human } \\
\text { Factor }\end{array}$ & Hedonism & $\begin{array}{l}\text { (Seligman, } \\
\text { Steen, Park, \& } \\
\text { Peterson, 2005) } 37\end{array}$ & 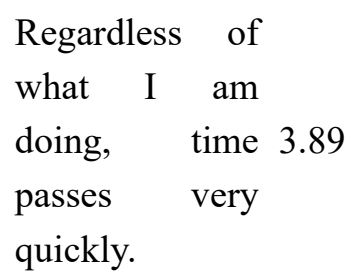 & 0.19 & -0.300 & 4.415 & 0.000 \\
\hline $\begin{array}{l}\text { Human } \\
\text { Factor }\end{array}$ & Hedonism & $\begin{array}{l}\text { (Seligman, } \\
\text { Steen, Park, \& } \\
\text { Peterson, 2005) } 38\end{array}$ & $\begin{array}{l}\text { I seek } \text { out } \\
\text { situations that } \\
\text { challenge } \\
\text { skills } 2.05 \\
\text { abilities. }\end{array}$ & 1.96 & -0.147 & 17.279 & 0.000 \\
\hline $\begin{array}{l}\text { Human } \\
\text { Factor }\end{array}$ & Hedonism & $\begin{array}{l}\text { (Seligman, } \\
\text { Steen, Park, \& } \\
\text { Peterson, 2005) }\end{array}$ & $\begin{array}{l}\text { Whether at } \\
\text { work or play, I } \\
\text { am usually "in } 3.53 \\
\text { a zone" and not } \\
\text { conscious of } \\
\text { myself. }\end{array}$ & 0.01 & 0.681 & 3.796 & 0.000 \\
\hline $\begin{array}{l}\text { Human } \\
\text { Factor }\end{array}$ & Hedonism & $\begin{array}{l}\text { (Seligman, } \\
\text { Steen, Park, \& } 40 \\
\text { Peterson, 2005) }\end{array}$ & $\begin{array}{l}\text { I am always } \\
\text { very absorbed } 3.61 \\
\text { in what I do. }\end{array}$ & 0.03 & -0.338 & 23.215 & 0.000 \\
\hline $\begin{array}{l}\text { Human } \\
\text { Factor }\end{array}$ & Hedonism & $\begin{array}{l}\text { (Seligman, } \\
\text { Steen, Park, \& } \\
\text { Peterson, 2005) }\end{array}$ & $\begin{array}{l}\text { In choosing } \\
\text { what to do, I } \\
\text { always take } \\
\text { into account } 2.58 \\
\text { whether I can } \\
\text { lose myself in } \\
\text { it. }\end{array}$ & 0.76 & -0.773 & 7.577 & 0.000 \\
\hline
\end{tabular}




\section{Macrothink Institute"}

\begin{tabular}{|c|c|c|c|c|c|c|c|}
\hline $\begin{array}{l}\text { Human } \\
\text { Factor }\end{array}$ & Hedonism & $\begin{array}{l}\text { (Seligman, } \\
\text { Steen, Park, \& } \\
\text { Peterson, 2005) }\end{array}$ & $\begin{array}{l}\text { I am rarely } \\
\text { distracted by } 2.51 \\
\text { what is going } \\
\text { on around me. }\end{array}$ & 0.88 & 0.570 & 6.141 & 0.000 \\
\hline
\end{tabular}

Human Resource Research

ISSN 1948-5441

2020, Vol. 4, No. 1

The questions used in this study were adopted from different past researches, it makes total of 42 instruments that were used. Above is their resources with respect to variables and factors. The first 4 set of questions are measuring Happiness which are scaled from 1 to 7 . The mean ranges from 3.75 to 5.35 and average mean is 4.84 , the overall mean suggested that responses are more towards above average ratings of this particular variable.

Remaining Five variables have a Likert scale of 1 to 5, where 1 represents the highest degree of disagreement and 5 reflects the most agreeableness. The second variable Individualism has a total of 5 questions with 3.74 to 4.15 range mean and average calculated mean 3.966 that show the moderate high agreeableness. Third variable Work Life Balance has a mean range of 2.45 to 3.13 and the general mean is 2.76 which reflects that most of the respondents had moderate response over these questions like they neither agree nor disagree.

Fourth Variable Career Development has 3.55 to 3.99 mean range with an average value of 3.784. The second last variable Learning has general average mean of 3.766 with ranging values from 3.66 to 3.86 both of these variables have slightly moderate higher responses from neutral point. The last variable Hedonism has total of 18 questions with an average mean of 3.02 and ranging from 2.05 to 3.96. Whereas all questions testing work life balance have a $P$ value more than 0 , rest of the instruments have value 0 . The 32 th instrument has the least outer loading which is -0.733 . Furthermore, all work life balance questions have the least values with average of 1.33 . Overall the tabulated results helped to evaluate findings of our study.

\subsection{Structural Equation Modeling}

To test the studied hypotheses, the structural equation model (SEM) was used through the Smart PLS software. Moreover, to evaluate the indirect and direct effects of all the constructs the testing was done. The use of (SEM) structural equation model has been observed to be a foremost procedure that has been used below different regression models and methods (Baron \& Kenny, 1986). It used to evaluate the structural relationship between exogenous and endogenous variables. It includes factor analysis and multivariate analysis. Moreover, the equation of regression targets at explaining each construct to assess the cause and effect relationship while all of the factors in the causal model could demonstrate their cause and effect at exact time. Likewise, the idea of using this model ensures to apply technique of bootstrapping which has been viewed as reasonable for both small and large sample size and does not require any kind of indirect effect (Hayes, 2013). In order to check the all direct and indirect effects, a technique has been implemented which is known as bootstrapping (Shrout \& Bolger, 2022) 


\section{Macrothink}

\subsubsection{Measurement of Outer Model}

The goal of measure of fit in the measurement model is to study about the reliability and validity of the instrument and to check its reliability and validity we perform test of convergent validity and discriminant validity in software naming Smart PLS.

\subsubsection{Composite Reliability}

Reliability implies stability of questionnaire outcomes. For the similar target population, at whatever point the questioner reutilize the questionnaire it will give similar outcome. It demonstrates inside consistency \& repeatability of the survey is high. The primary measure for unwavering quality is to maintain a strategic distance from unfairness in research. In this manner, it tends to be improved by testing the pursuit procedure and investigation, as is done utilizing diverse research and examination techniques or different researchers. This also incorporates the dependability and legitimacy of the exploration.

Reliability of the measurement instruments was evaluated using composite reliability. All the values were above the normally used threshold value i.e. 0.70 . This is the accepted reliability value range. Estimation of reliability can be done by degree of constancy that lies amongst various variables.

\subsubsection{Factor Loadings Significant}

Table of descriptive statistics also mentioned loadings used in (CFA) confirmatory factor analysis. Construct with the loading of .5 are consider as strong loading variables whereas the constructs with the loading of below .5 are considered as less are better to be removed from the table.

\subsubsection{Convergent Validity}

Convergent validity is the degree of consensus in two or more identical measurements (Carmines \& Zeller, 1979) Convergent validity had obtained by depth analysis of variance mined for every factor (Fornell \& Larcker, 1981). Bestow on (Fornell \& Larcker, 1981), if the, variance obtained value is above and more than 0.5 then convergent validity is confirmed and the obtained result is pinched that the loadings are well enough but lesser value than 0.5 are termed as less effective for study.

Following Table 3. Is displaying the result:

Table 3. Reliability and validity statistics

\begin{tabular}{llllll}
\hline Construct & Item & Factor Loading & AVE & CB Alpha & CR \\
\hline Career Development & CD1 & 0.836 & 0.838 & 0.798 & 0.467 \\
& CD2 & 0.576 & & & \\
& CD3 & 0.278 & & & \\
& CD4 & 0.688 & & & \\
& CD5 & 0.866 & & & \\
\hline
\end{tabular}




\begin{tabular}{|c|c|c|c|c|c|}
\hline \multirow[t]{17}{*}{ Hedonism } & $\mathrm{H} 1$ & 0.656 & \multirow{17}{*}{\multicolumn{2}{|c|}{$0.265 \quad 0.066$}} & \multirow[t]{17}{*}{0.271} \\
\hline & H10 & -0.274 & & & \\
\hline & H11 & -0.567 & & & \\
\hline & H12 & -0.300 & & & \\
\hline & H13 & -0.147 & & & \\
\hline & $\mathrm{H} 14$ & 0.681 & & & \\
\hline & $\mathrm{H} 15$ & -0.338 & & & \\
\hline & H16 & -0.773 & & & \\
\hline & $\mathrm{H} 17$ & 0.570 & & & \\
\hline & $\mathrm{H} 18$ & 0.369 & & & \\
\hline & $\mathrm{H} 2$ & 0.725 & & & \\
\hline & $\mathrm{H} 3$ & 0.417 & & & \\
\hline & $\mathrm{H} 4$ & 0.375 & & & \\
\hline & $\mathrm{H} 5$ & 0.509 & & & \\
\hline & H6 & 0.570 & & & \\
\hline & $\mathrm{H} 7$ & -0.337 & & & \\
\hline & $\mathrm{H} 8$ & -0.773 & & & \\
\hline \multirow[t]{4}{*}{ Happiness } & HA1 & 0.567 & \multirow[t]{4}{*}{0.411} & 0.482 & 0.357 \\
\hline & HA2 & 0.469 & & & \\
\hline & HA3 & 0.871 & & & \\
\hline & HA4 & -0.361 & & & \\
\hline
\end{tabular}

\begin{tabular}{llllll}
\hline Individualism (Culture) & IC1 & 0.386 & 0.734 & 0.705 & 0.352 \\
& IC2 & 0.351 & & & \\
& IC3 & 0.824 & & & \\
& IC4 & 0.784 & & & \\
& IC5 & 0.440 & & & \\
\hline Learning & TP2 & 0.798 & 0.830 & 0.828 & 0.502 \\
& TP3 & 0.816 & & & \\
& TP4 & 0.783 & & & \\
& TP5 & 0.652 & & & \\
& TP6 & 0.411 & & & \\
\hline Moderating Effect & Hedonism * Individualism Culture 1.000 & 1.000
\end{tabular}




\begin{tabular}{llllll}
\hline Work Life Balance & WL1 & 0.193 & 0.565 & 0.559 & 0.251 \\
& WL2 & 0.849 & & & \\
WL3 & 0.291 & & & \\
WL4 & 0.262 & & \\
WL5 & 0.585 & & \\
\hline
\end{tabular}

The above table illustrates the reliability and validity of the data. The factor loading of different instruments are illustrated above. Starting from Career Development, except for the question $2 \& 3$ all have factor loading above than 0.60. In Hedonism there were 18 questions and factor loading shows variety of values few negative $\&$ most of them are positive ranging overall from -0.773 to 0.656 . Happiness factor loading is ranging from -0.361 to 0.871 and total question were four. Individualism (Culture) loading varying from 0.386 to 0.824 . Variable Learning has five questions and its factor loading varying from 0.411 and goes to 0816. Work Life Balance valued from 0.193 till 0.849.

The Variance of factors including Career development, Learning, Work life balance, individualism culture, Hedonism and Happiness is ranging from 0.265 to 0.838 where most of their values are higher than 0.5 which is a good sign. Croanbach alpha of hedonism is less which is 0.265 while other factors 0.411 to 0.838 which are satisfactory \& two of them are higher than 0.7 which is perfect. Whereas Composite Reliability 0.251 till 0.502 .

\subsubsection{Discriminant Validity}

Discriminate validity could be described as a single structure if it differs from other models (Carmines \& Zeller, 1979) Discriminate validity test outcome are moderator when the constructs are having an AVE loading above than 0.5 which means that minimum $50 \%$ of variance was obtained by the construct (Chin, 1998). Discriminate validity is formed if the elements which are in diagonal are significantly above than those values in off-diagonal in the parallel rows and columns. Discriminant validity tests are now being performed to see if unconnected ideas or measurements are actually irrelevant or not. An efficient evaluation of discriminating legitimacy shows that a trial of a concept is not exceptionally associated with various tests aimed at hypothetically quantifying different ideas. The table 4. For Discriminant Validity is given below:

Table 4. Fornell larcker criteria

\begin{tabular}{lllllll}
\hline & CD & Happiness & Hedonism & $\begin{array}{l}\text { Ind } \\
\text { Culture }\end{array}$ & $\begin{array}{l}\text { Learning } \\
\text { Moderating WLB } \\
\text { Effect 1 }\end{array}$ \\
\hline $\begin{array}{l}\text { Career } \\
\text { Development }\end{array}$ & 0.683 & & & & \\
Happiness & 0.267 & 0.598 & & & \\
Hedonism & -0.647 & -0.647 & 0.520 & & & \\
\hline
\end{tabular}




\begin{tabular}{llllllll}
\hline Ind Culture & 0.558 & 0.430 & -0.654 & 0.593 & & & \\
Learning & 0.601 & 0.557 & -0.808 & 0.693 & 0.709 & & \\
Moderating & 0.296 & 0.043 & -0.429 & 0.508 & 0.322 & 1.000 & \\
Effect 1 & & & & & & & \\
WLB & 0.127 & 0.355 & -0.465 & 0.042 & 0.353 & -0.102 & 0.501 \\
\hline
\end{tabular}

According to the Fornell-Larcker criterion, which is about discriminant validity of data, value of AVE must be greater than the square of correlation coefficient $b / w$ constructs.

Above given table shows the correlation coefficient of instruments, where career Development has highest value in its pillar which is 0.683 and second among all. Next one is Happiness which has value of 0.598 and its highest in its post. Third one is Hedonism and it has 0.520 which is greater than others of his column. Next is Individualism (Hofstede Culture) whose value is second in chain as here value of learning is superseding it and Individualism has value of 0.593 . Learning has $0.709 \&$ in the end work life balance has 0.501 .

Table 5. Correlation analysis

\begin{tabular}{llllllll}
\hline & CD & Happiness & Hedonism & $\begin{array}{l}\text { Individualism Learning } \\
\text { Culture }\end{array}$ & $\begin{array}{l}\text { Moderating } \\
\text { Effect } 1\end{array}$ & WLB \\
\hline $\begin{array}{l}\text { Career } \\
\text { Development }\end{array}$ & 1.000 & 0.267 & -0.647 & 0.558 & 0.601 & 0.533 & 0.127 \\
$\begin{array}{l}\text { Happiness } \\
\text { Hedonism }\end{array}$ & 0.267 & 1.000 & -0.647 & 0.430 & 0.557 & 0.078 & 0.355 \\
$\begin{array}{l}\text { Individualism } \\
\text { Culture }\end{array}$ & 0.558 & 0.430 & -0.654 & 1.000 & 0.693 & 0.915 & 0.042 \\
Learning & 0.601 & 0.557 & -0.808 & 0.693 & 1.000 & 0.580 & 0.353 \\
Moderating & 0.533 & 0.078 & -0.774 & 0.915 & 0.580 & 3.245 & -0.183 \\
Effect 1 & & & 1.000 & -0.654 & -0.808 & -0.774 & -0.465 \\
WLB & 0.127 & 0.355 & -0.465 & 0.042 & 0.353 & -0.183 & 1.000 \\
\hline
\end{tabular}

The above Table 5 shows relationship of variables with one another within the research. Career Development, Happiness, Individualism, Learning and Work life balance have positive and significant relationship among but with Hedonism it is negative simultaneously with all.

\subsubsection{Model Fit Measures}

The strength of the model in SEM-PLS is Defined by different measures, including standardized root-mean-square residual (SRMR), and the exact model fits like d_ULS and d_G, Normed Fit Index (NFI), and $\chi 2$ (Chi-square). The model fit measures consisting the 


\section{Macrothink}

Human Resource Research

ISSN 1948-5441 2020, Vol. 4, No. 1

measured value of both saturated model and in addition the estimated model also is listed in table above. The saturated model judges the correlation among all constructs. The approximate model, else ways, takes model structure into account and is based on total effect scheme.

Table 6. Fit summary

\begin{tabular}{lll}
\hline & Saturated Model & Estimated Model \\
\hline SRMR & 0.124 & 0.125 \\
d_ULS & 13.787 & 14.077 \\
d_G & 6.274 & 6.269 \\
Chi-Square & $5,123.835$ & $5,141.734$ \\
NFI & 0.299 & 0.296 \\
\hline
\end{tabular}

Table 7. Model summary

\begin{tabular}{lll}
\hline & R Square & R Square Adjusted \\
\hline Happiness & 0.497 & 0.490 \\
Hedonism & 0.740 & 0.736 \\
\hline
\end{tabular}

Table 7 shows the R square value of happiness which 0.497 (49.7\%) \& Hedonism has 0.740 (74\%), whereas R Square adjusted values are 0.490 (49\%) and 0.736 (73.6\%) for Happiness and Hedonism respectively, $\mathrm{R}$ square shows the impact and the impacts are good and impactful.

\subsection{Hypothesis Testing}

In PLS-SEM Bootstrapping has been one of the important steps which provides the variable estimate constancy details. Sub-tests are taken everywhere, including replacement, from the first case, in this method. (Hair, Matthews, Matthews, \& Sarstedt, 2017). The bootstrapping offers coefficient estimation stability knowledge. In this method a large number of subsamples are taken with removal from the original sample (Hair Jr, Sarstedt, Matthews, \& Ringle, 2016). SmartPLS shows the t-values for structural model projections extracted from the bootstrapping operation after operating the bootstrap regimen. The outcomes of path coefficients for all the hypothesis are shown in the following table \& the path diagram showed in Figure 2 below. 


\section{Macrothink}

Human Resource Research

ISSN 1948-5441

2020, Vol. 4, No. 1

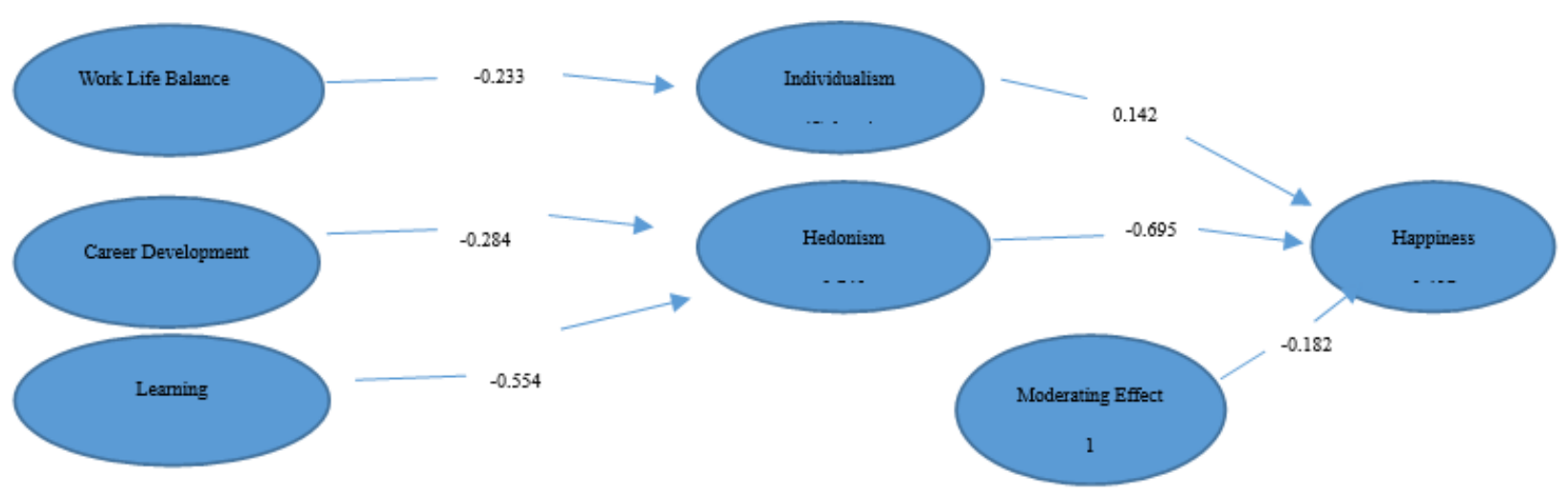

Figure 2. Path diagram

Table 7. Standard Deviation, T values, $\mathrm{P}$ values \& Decision

Hypothesis

Standard Deviation (STDEV) T-values P -values Decision

\begin{tabular}{lcccc}
\hline Career Development -> Hedonism & 0.052 & 5.498 & 0.000 & Supported \\
Hedonism -> Happiness & 0.069 & 7.928 & 0.000 & Supported \\
Individualism Culture -> Happiness & 0.068 & 1.873 & 0.062 & Not Supported \\
Learning -> Hedonism & 0.054 & 9.304 & 0.000 & Supported \\
Moderating Effect 1 -> Happiness & 0.046 & 3.094 & 0.002 & Supported \\
Work Life Balance -> Hedonism & 0.123 & 1.669 & 0.096 & Not Supported \\
\hline
\end{tabular}

Above Table 7. Shows that all hypotheses are accepted except for the effect of Individualism on Happiness and Effect of Work life balance on Hedonism with 0.062 and 0.096 P- values respectively.

\subsubsection{Total Effect}

Table 8. Path coefficients

\begin{tabular}{lll}
\hline & Happiness & Hedonism \\
\hline $\mathrm{CD}$ & 0.198 & -0.284
\end{tabular}

Happiness

Hedonism

Individualism Culture

0.142

Learning

0.385

$-0.554$ 
Above Table 8 demonstrates the total effect of whole research model, the standard coefficient of Career development with Happiness \& hedonism are $0.198 \&-0.284$ respectively. While Learning has values 0.385 and -0.554 with happiness and hedonism simultaneously. Work Life Balance has 0.162 and -0.2333 values with happiness and hedonism. Relationship between Happiness and Hedonism is -0.695 .

Table 9. Hypotheses testing

\begin{tabular}{lll}
\hline & T Statistics $(|\mathrm{O} / \mathrm{STDEV}|)$ & P Values \\
\hline CD -> Hedonism & 5.498 & 0.000 \\
Hedonism -> Happiness & 7.928 & 0.000 \\
Ind Culture -> Happiness & 1.873 & 0.062 \\
L -> Hedonism & 9.304 & 0.000 \\
Moderating Effect 1 -> Happiness & 3.094 & 0.002 \\
WLB -> Hedonism & 1.669 & 0.096 \\
\hline
\end{tabular}

In Table 9, all the hypotheses are accepted on the basis of $\mathrm{p}$ value except Individualism Culture -> Happiness \& WLB -> Hedonism are not seeming to be impact full.

Table 10. Specific indirect effects

\begin{tabular}{ll}
\hline & Specific Indirect Effects \\
\hline CD -> Hedonism -> Happiness & 0.198 \\
L -> Hedonism -> Happiness & 0.385 \\
WLB -> Hedonism -> Happiness & 0.162 \\
\hline
\end{tabular}

The above Table 10 stats that there is a moderate relation among career development and happiness in which hedonism mediates the relationship similarly work life balance has effect on happiness where hedonism is mediating. Lastly there is a relationship among Learning and Happiness and Hedonism mediates it but link is less strong than other two because it has value of 0.3 whereas 0.1 value shows the strongest relations. 


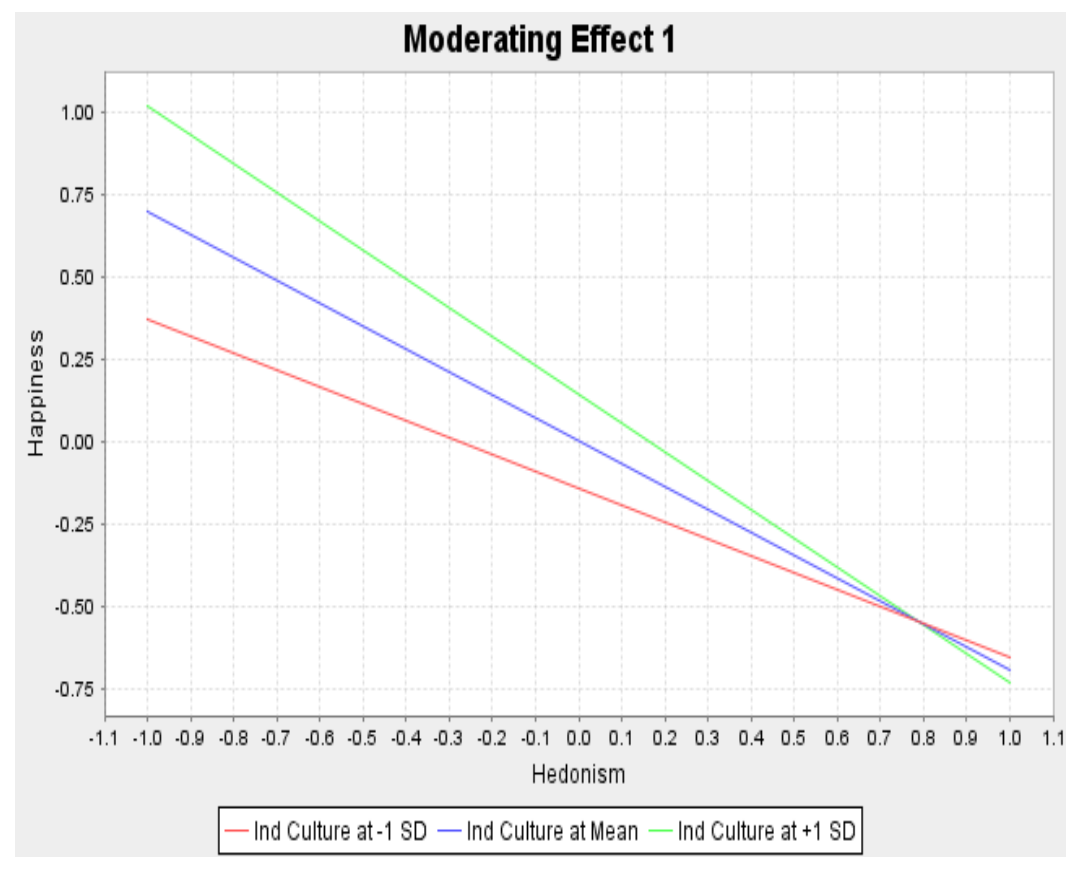

Figure 3.

The above Figure 3 illustrates the Moderating effect of Individualism culture over the relationship of Hedonism on Happiness. Where the values of mean with standard deviations has been compared and it intersected at the coordinates of $(0.75,0.55)$.

The first hypothesis of the study has $\mathrm{p}$ value of 0.096 which results in the rejection of hypothesis that means there no significant positive effect of work life balance on hedonism. Second hypothesis of study stands with the $p$ value of 0.00 which makes it us to say that there is a significant positive effect of career development on hedonism. Third hypothesis has $p$ value of 0.00 which proves that learning has significant and positive effect on Hedonism. Fourth hypothesis has value of 0.00 which proves that there is a significant effect of individualism as a moderator on the relationship with happiness. Fifth Hypothesis has again value of 0.00 which proves that there is a positive and significant relationship among hedonism and happiness. Show that people with progressive attitudes and career-coping strategies were more able to achieve greater well-being.

\section{Discussions}

The findings of the research indicating that there is significant positive relationship of career development on Hedonism (Pleasure) that means an employee at who has better career development chances at his workplace will be more satisfied and enjoying his job. As per (Merchant Jr, 2010) Career development system enhances long-term workplace output and supports staff with possible concerns.

Furthermore, it has been observed from findings that there is positive relation of Learning of an employee at workplace with Hedonism that elaborates that workers feel highly motivated and satisfied when there is a continuous learning process at workplace. According to (Daniels \& Harris, 2000) Working satisfaction that has a significant positive effect on work 
performance means that the higher the learning they have an enormous amount of energy, seeing pleasure in some items and seeing love in some stuff, the more the workers do because they are appreciated to achieve the goals at work.

Thirdly. results reflects that their no significant effect of work life balance on Hedonism although that means work life balance does not affects Hedonism that contradicts of early findings that correlates or showed positive relationship among same likely according to (Haar, Russo, Suñe, \& Ollier-Malaterre, 2014) High concentrations of WLB have been correlated more favorably with work and life satisfaction and more poorly with distress in gender-equalitarian societies for individuals. Generally, as a representative of these partnerships, we find strong appreciation for WLB being of interest to workers from different cultures and for community. Whereas the mentioned study covered various countries but our study is focusing on Pakistani Culture so contradiction of this study is valid as they generalizes their result based upon the bunch of countries. Precisely WLB has insignificant effect on Hedonism.

Discussing further the findings showed the positive effect of Learning and Career development at workplace with Hedonism. The result reflected the positive relation of Hedonism with Happiness that intricate that when an individual's Hedonism is high the graph of Happiness of an employee will rise also as they both are correlated According (Joshanloo \& Jarden, 2016) the link between hedonism and pleasure shown in the chart has been greater. The base paper also regulates the same idea in the context of 19 nations and our finding showed that it also applies for Pakistani context.

Lastly, statistical finding of our study reflected the positive and significant moderator effect of individualism/ collectivism culture on happiness additionally study reflect that there is no direct effect of individualism on Happiness is present. This relation justifies that Happiness of employee may vary with the culture they have regulating at their workplace. According to (Layous \& Lyubomirsky, 2015) the efficacy of expressing those ideals in generating happiness will rely on culture.

The different studies on this topic also reflected the same sort of results but there was a gap to take up in it in organization cultural context. According to (Jabeen \& Khan, 2016) analyzed the determinants of joy in Pakistan for individual people and unrevealed that there is a need for lawmakers to enact social welfare programs to raise people's incomes and boost population health status. For getting better happiness in the society. As the referenced study is covering whole society culture but our study is more specific to organizational culture.

The Result of empirical study reflected that there is a positive significant effect of learning at workplace, career development prospects for an individual at workplace on hedonism (valuing pleasure) and Hedonism as mediator is significant, and have high impact on Happiness of an individual at workplace whereas individualism vs Collectivisms Hofstede Cultural Dimension has positive moderating effect on the relationship of Hedonism on Happiness.

\section{Conclusion}

This study was based on a paper of (Joshanloo \& Jarden, 2016) studying the impact of hedonism on happiness in an individualistic culture which presented the relationship between 


\section{$\Lambda$ Macrothink}

happiness and hedonism are much stronger in individualistic culture as compared to collectivistic culture.

In this current study, the researcher has intended to further add to the literature and expand the knowledge of this area of study by testing the effect of the variables of work life balance, learning and career development on happiness where Hedonism is a mediator while Individualism vs collectivism (Hofstede cultural dimensions) moderates the effect on the Pakistani workforce.

The study had different phases in which data was collected from 290 individuals working in private, semi private and public sectors of Pakistan who are employed in various departments like HR, Marketing, Supply Chain, Finance, etc., through the instrument of a questionnaire which adopted questions from different sources to test the variables. The results indicate that, in an individualistic culture, when hedonism is taken as a mediator, there is a significant positive effect of learning and career development on happiness, unlike work life balance, which does not have a significant positive impact on happiness.

Hence, it can be stated that career development and learning are strong factors that employers can focus on to keep their Pakistani workforce happy, which is very important for the mental wellbeing of employees. The psychological health of employees is very essential but is yet to be explored in detail in the Pakistani context.

Happiness and mental fitness are factors that should be focused by employers as they ultimately impact the productivity of employees. This paper attempts to shed some light on this topic and give a direction for future researched to follow. The results indicate that when employees are able to see the direction of their career growth within their organization (career development) and when they believe that they have the opportunity to acquire new skills and competencies and enhancing their knowledge through learning, they have a better chance of being happy and joyful within their workplace as compared to when they are given the chance to juggle and balance their daily routine work in the professional workplace with their personal lives (work life balance) in their pursuit of pleasure (that is hedonism). Furthermore, the hypothesis testing the relationship between individualistic cultures with happiness has been rejected which show that there is no significant association of happiness with the type of culture observed in any organization.

Moreover, the significant association of hedonism with happiness indicate that the desire, willingness and pursuit of happiness is crucial for an employee to ultimately be happy within the work environment. If a person does not struggle or make efforts to keep he or she joyful then the chances of them maintaining a satisfactory level of happiness is quite unrealistic.

The findings of this study aim to benefit the organizations working in Pakistan as the results of this study it will be helpful for them to increase the scale of happiness of their employees $\&$ for particularly government this study will be beneficial to enhance or to change certain aspects of making an employee happy.

This study was overall based on quantitative research in which the instrument was adopted and furthermore, the overall data was collected from the popular organizations working in Pakistan which includes private government and semi-private organizations while the respondents were from almost every department. 


\section{Macrothink}

This result opens new avenues for future studies to explore the reasons of why work life balance does not equally impact happiness in Pakistani employees as compared to learning and career development. Future researches can also support this study by covering its limitations. For instance, this study only focuses on the developing country of Pakistan, specifically in the city of Karachi, which provides the opportunity for future researches to focus in other cities of Pakistan, or can even expand to explore the relationship of the variables in other regions or in developed countries, like United States of America, Australia, etc.

Moreover, future studies can shed some light on how other similar variables, like motivation, or job satisfaction have an impact on Happiness. Even more, the roles played by the variables can be studied in a vice versa manner, that is, to see how happiness impacts the variables of work life balance, learning and career development in an individualistic culture.

\section{References}

Adnan Bataineh, K. (2019). Impact of work-life balance, happiness at work, on employee performance. International Business Research, 12(2), 99-112. https://doi.org/10.5539/ibr. v12n2p99

Akkermans, J., Brenninkmeijer, V., Huibers, M., \& Blonk, R. W. (2013). Competencies for the contemporary career: Development and preliminary validation of the Career Competencies Questionnaire. Journal of Career Development, 40(3), 245-267. https://doi.org/10.1177/0894845312467501

Akkermans, J., Paradniké, K., Van der Heijden, B. I., \& De Vos, A. (2018). The best of both worlds: the role of career adaptability and career competencies in students' well-being and performance. Frontiers in psychology, 9, 1678. https://doi.org/10.3389/fpsyg.2018.01678

Al-Ali, W., Ameen, A., Isaac, O., Khalifa, G. S., \& Shibami, A. H. (2019). The mediating effect of job happiness on the relationship between job satisfaction and employee performance and turnover intentions: A case study on the oil and gas industry in the United Arab Emirates. Journal of Business and Retail Management Research, 13(4). https://doi.org/10.24052/JBRMR/V13IS04/ART-09

Azara, S., Khana, A., \& Van Eerdeb, W. (2018). Modelling linkages between flexible work arrangements'. Journal of Business Research, 134-143. https://doi.org/10.1016/j.jbusres. 2018.06.004

Aziz-Ur-Rehman, M., \& Siddiqui, D. A. (2019). Relationship between Flexible Working Arrangements and Job Satisfaction Mediated by Work-Life Balance. Evidence from Public Sector Universities Employees of Pakistan. https://doi.org/10.2139/ssrn.3510918

Balaji, R. (2016). A study on quality of work life among employees. International Journal of Innovative Research in Science, Engineering and Technology.

Baron, R. M., \& Kenny, D. A. (1986). The moderator-mediator variable distinction in social psychological research: Conceptual, strategic, and statistical considerations. Journal of Personality and Social Psychology, 51(6), 1173-1182. https://doi.org/10.1037/0022-3514. 51.6.1173

Baumeisteer, R. F. (2005). The cultural animal: Human nature, meaning, and social life. Oxford University Press. 


\section{Macrothink}

Human Resource Research

ISSN 1948-5441

2020, Vol. 4, No. 1

Baumeister, R. F., \& Tierney, J. (2011). Willpower: Rediscovering the greatest human strength. New York. Penguin Press.

Belias, D., \& Koustelios, A. (2014). Organizational culture and job satisfaction of Greek banking institutions. Procedia-Social and Behavioral Sciences, 175(1), 314-323. https://doi.org/10.1016/j.sbspro.2015.01.1206

Boehm, J. K., Lyubomirsky, S., \& Sheldon, K. M. (2011). A longitudinal experimental study comparing the effectiveness of happiness-enhancing strategies in Anglo Americans and Asian Americans. Cognition \& Emotion, 25(7), 1263-1272. https://doi.org/10.1080/02699931. 2010.541227

Brough, P., Timms, C., O'Driscoll, M. P., Kalliath, T., Siu, O. L., Sit, C., \& Lo, D. (2014). Work-life balance: A longitudinal evaluation of a new measure across Australia and New Zealand workers. The International Journal of Human Resource Management, 25(19), 2724-2744. https://doi.org/10.1080/09585192.2014.899262

Carmines, E. G., \& Zeller, R. A. (1979). Reliability and validity assessment (Vol. 17). Sage publications. https://doi.org/10.4135/9781412985642

Chaiprasit, K. \&. (2011). Happiness at work of employees in small and medium-sized enterprises, Thailand. Procedia-Social and Behavioral Sciences, 25, 189-200.

Chait Barnett, R., Gareis, K. C., \& Brennan, R. T. (2008). Wives' shift work schedules and husbands' and wives' well-being in dual-earner couples with children: A within-couple analysis. Journal of family Issues, 29(3), 396-422. https://doi.org/10.1177/0192513X 07305346

Chin, W. W. (1998). Commentary: Issues and opinion on structural equation modeling.

Chung, H., \& Van der Lippe, T. (2018). Flexible working, work-life balance, and gender equality: Introduction. Social Indicators Research, 1-17. https://doi.org/10.1007/s11205-018 $-2025-\mathrm{x}$

Daniels, K., \& Harris, C. (2000). Work, psychological well-being and performance. Occupational Medicine, 50(5), 304-309. https://doi.org/10.1093/occmed/50.5.304

DeCenzo, D. A., Robbins, S. P., \& Verhulst, S. L. (2016). Fundamentals of human resource management. John Wiley \& Sons.

Diener, E., Tay, L., \& Myers, D. G. (2011). The religion paradox: If religion makes people happy, why are so many dropping out? Journal of personality and social psychology, 101(6), 1278. https://doi.org/10.1037/a0024402

Fan, J., \& Smith, A. (2017). Positive well-being and work-life balance among UK railway staff. Open Journal of Social Sciences, 5, 1-6. https://doi.org/10.4236/jss.2017.56001

Fornell, C., \& Larcker, D. F. (1981). Structural equation models with unobservable variables and measurement error. Algebra and statistics. https://doi.org/10.1177/002224378101800104 Fujimoto, Y., \& Härtel, C. (2006). A self-representation analysis of the effects of individualist-collectivist interactions within organizations in individualistic cultures. Cross Cultural Management: An International Journal. https://doi.org/10.1108/135276006106 83354 


\section{MInstitute Macrothink $_{\text {Int }}$}

Human Resource Research

ISSN 1948-5441 2020, Vol. 4, No. 1

Goffee, R., \& Scase, R. (1992). Organizational change and the corporate career: The restructuring of managers' job aspirations. Human Relations, 45(4), 363-385. https://doi.org/10.1177/001872679204500404

Grant, A. M., Christianson, M. K., \& Price, R. H. (2007). Happiness, health, or relationships? Managerial practices and employee well-being tradeoffs. Academy of management perspectives, 21(3), 51-63. https://doi.org/10.5465/amp.2007.26421238

Greenhaus, J. H., Collins, K. M., \& Shaw, J. D. (2003). The relation between work-family balance and quality of life. Journal of vocational behavior, 63(3), 510-531. https://doi.org/10.1016/S0001-8791(02)00042-8

Gupta, S. (2014). Research Paper on Emotional Intelligence and Work Life Balance of Employees in the Information Technology Industry. Journal of Information Technology. https://doi.org/10.2139/ssrn.2395216

Haar, J. M., Russo, M., Suñe, A., \& Ollier-Malaterre, A. (2014). Outcomes of work-life balance on job satisfaction, life satisfaction and mental health: A study across seven cultures. Journal of Vocational Behavior, 85(3), 361-373. https://doi.org/10.1016/j.jvb.2014.08.010

Hair Jr, J. F., Sarstedt, M., Matthews, L. M., \& Ringle, C. M. (2016). Identifying and treating unobserved heterogeneity with FIMIX-PLS: part I-method. European Business Review. https://doi.org/10.1108/EBR-09-2015-0094

Hair, J. F., Matthews, L. M., Matthews, R. M., \& Sarstedt, M. (2017). PLS-SEM or CB-SEM: updated guidelines on which method to use. Int. J. Multivariate Data Analysis, 107-123. https://doi.org/10.1504/IJMDA.2017.10008574

Hartel, C. E., Fujimoto, Y., Strybosch, V. E., \& Fitzpatrick, K. (2006). Human resource management: Transforming theory into innovative practice. Pearson Education Australia.

Hayes, A. F. (2013). Introduction to Mediation, Moderation, and Conditional Process Analysis: A Regression-Based Approach. The Guilford Press. Journal of Educational Measurement, 335-337.

Higgins, E. T. (1997). Beyond pleasure and pain. American psychologist, 52(12), 1280. https://doi.org/10.1037/0003-066X.52.12.1280

Ismail, A., Adnan, N. H., \& Bakar, R. A. (2014). Perceived career development support in workplace career programme. Economic Annals, 59(201), 157-175.

Jabeen, F., \& Khan, F. A. (2016). An Empirical Analysis of Individual's Happiness in Pakistan. Putaj Humanities \& Social Sciences, 23(2).

Johnston,, C. S., Luciano, E. C., Maggiori, C., Ruch, W., \& Rossier, J. (2013). Validation of the German version of the Career Adapt-Abilities Scale and its relation to orientations to happiness and work stress. Journal of Vocational Behavior, 83(3), 295-304. https://doi.org/10. 1016/j.jvb.2013.06.002

Joo, B. K., \& Lee, I. (2017). Workplace happiness: work engagement, career satisfaction, and subjective well-being. In Evidence-based HRM: A Global Forum for Empirical Scholarship. Emerald Publishing Limited. https://doi.org/10.1108/EBHRM-04-2015-0011 


\section{MInstitute Macrothink $_{\text {Ins }}$}

Joshanloo, M. (2014). Eastern conceptualizations of happiness: Fundamental differences With western views. Journal of Happiness Studies, 15(2), 475-493. https://doi.org/10.1007/ s10902-013-9431-1

Joshanloo, M., \& Jarden, A. (2016). Individualism as the moderator of the relationship between hedonism and happiness: A study in 19 nations. Personality and Individual Differences. Elsevier, 94, 149-152. https://doi.org/10.1016/j.paid.2016.01.025

Karkoulian, S., Srour, J., \& Sinan, T. (2016). A gender perspective on work-life balance, perceived stress, and locus of control. Journal of Business Research, 69(11), 4918-4923. https://doi.org/10.1016/j.jbusres.2016.04.053

Kaya, C., \& Ceylan, B. (2014). An empirical study on the role of career development programs in organizations and organizational commitment on job satisfaction of employees. American Journal of Business and Management, 3(3), 178-191. https://doi.org/10.11634/ 216796061403551

Kitayama, S., \& Markus, H. R. (2000). The pursuit of happiness and the realization of sympathy: Cultural patterns of self, social relations, and well-being. Culture and subjective well-being, 1, 113-161.

Knoke, D. (2018). Changing organizations: Business networks in the new political economy. Routledge. https://doi.org/10.4324/9780429501753

Kyndt, E., Dochy, F., \& Nijs, H. (2009). Learning conditions for non-formal and informal workplace learning. Journal of Workplace Learning. https://doi.org/10.1108/13665 620910966785

Layous, K., \& Lyubomirsky, S. (2015). Thinking about rumination: The scholarly contributions and intellectual legacy of Susan Nolen-Hoeksema. Annual review of clinical psychology, 11, 1-22. https://doi.org/10.1146/annurev-clinpsy-032814-112733

Littlejohn, A., \& Margarayn, A. (2011). Collective learning in the workplace: Important knowledge sharing behaviours. International Journal of Advanced Corporate Learning (iJAC), 4(4), 26-31. https://doi.org/10.3991/ijac.v4i4.1801

Lockwood, N. R. (2003). Work/life balance. Challenges and Solutions. SHRM Research.

Lu, L., Gilmour, R., \& Kao, S. F. (2001). Cultural values and happiness: An East-West dialogue. The Journal of Social Psychology, 141(4), 477-493. https://doi.org/10.1080/002245 40109600566

Lundvall, B. A., Rasmussen, P., \& Lorenz, E. (2008). Education in the Learning Economy: a European perspective. Policy futures in education, 6(6), 681-700. https://doi.org/10.2304/pfie. 2008.6.6.681

Lyubomirsky, S., \& Lepper, H. S. (1999). A measure of subjective happiness: Preliminary reliability and construct validation. Social indicators research, 46(2), 137-155. https://doi.org/10.1023/A:1006824100041

Malik, M. I., Gomez, S. F., Ahmad, M., \& Saif, M. I. (2010). Examining the relationship of work life balance, job satisfaction and turnover in Pakistan. OIDA International Journal of Sustainable Development, 2(01), 27-33. 


\section{$\triangle$ Macrothink}

Man, D. C., \& Lam, S. S. (2003). The effects of job complexity and autonomy on cohesiveness in collectivistic and individualistic work groups: a cross-cultural analysis. Journal of Organizational Behavior: The International Journal of Industrial, Occupational and Organizational Psychology and Behavior, 24(8), 979-1001. https://doi.org/10.1002/ job. 227

Manuti, A., Pastore, S., Scardigno, A. F., Giancaspro, M. L., \& Morciano, D. (2015). Formal and informal learning in the workplace: a research review. International journal of training and development, 19(1), 1-17. https://doi.org/10.1111/ijtd.12044

McCort, D. J., \& Malhotra, N. K. (1993). Culture and consumer behavior: toward an understanding of cross-cultural consumer behavior in international marketing. Journal of International Consumer Marketing, 6(2), 91-127. https://doi.org/10.1300/J046v06n02_07

Merchant Jr, R. C. (2010). The role of career development in improving organizational effectiveness and employee development. Florida Department of Law Enforcement.

Oishi, S., \& Gilbert, E. A. (2016). Current and future directions in culture and happiness research. Current Opinion in Psychology, 8, 54-58. https://doi.org/10.1016/j.copsyc.2015. 10.005

Otken, A. B., \& Erben, G. S. (2013). The relationship between work-life balance and happiness from the perspectives of generation $\mathrm{X}$ and Y. Humanities and Social Science Review, 2(4), 45-53.

Pan, J., \& Zhou, W. (2013). Can success lead to happiness? The moderators between career success and happiness. Asia Pacific Journal of Human Resources, 51(1), 63-80. https://doi.org/10.1111/j.1744-7941.2012.00033.x

Sagiv, L., Roccas, S., \& Oppenheim-Weller, S. (2015). Values and Well-Being. Positive psychology in practice: Promoting human flourishing in work, health, education, and everyday life. 103-120. https://doi.org/10.1002/9781118996874.ch7

Saleem, S., \& Amin, S. (2013). The impact of organizational support for career development and supervisory support on employee performance: An empirical study from Pakistani academic sector. European Journal of Business and Management, 5(5), 194-207.

Schmeichel, B. J., Vohs, K. D., \& Baumeister, R. F. (2003). Intellectual performance and ego depletion: role of the self in logical reasoning and other information processing. Journal of personality and social psychology, 85(1), 33. https://doi.org/10.1037/0022-3514.85.1.33

Schwartz, B. (2015). The paradox of choice. In S. Joseph (Ed.), Positive psychology in Practice: Promoting human flourishing in work, health, education, and everyday life. Hoboken, NJ: Wiley. https://doi.org/10.1002/9781118996874.ch8

Schwartz, S. H. (2009). Culture matters: National value cultures, sources and consequences. In C. -Y. Chiu, Y. Y. Hong, S. Shavitt, \& R. S. WyerJr. (Eds.), Understanding Culture: Theory. New York: Psychology Press.

Seligman, M. E., Steen, T. A., Park, N., \& Peterson, C. (2005). Positive psychology progress: empirical validation of interventions. American psychologist, 60(5), 410. 


\section{Macrothink}

Human Resource Research

ISSN 1948-5441

2020, Vol. 4, No. 1

Shrout, P. E., \& Bolger, N. (2022). Mediation in experimental and nonexperimental studies: new procedures and recommendations. Psychological methods, 7(4), 422. https://doi.org/10. 1037/1082-989X.7.4.422

Soares, A. M., Farhangmehr, M., \& Shoham, A. (2007). Hofstede's dimensions of culture in international marketing studies. Journal of business research, 60(3), 277-284.

Sohaib, M., Ihsaan, I., Yousaf, J., \& Majeed, A. (2015). Factors affecting the organizational learning: a study of banking sector of Pakistan. Studies, 2(2).

Tamir, M., \& Mauss, I. B. (2011). Social cognitive factors in emotion regulation: Implications for well-being. In Emotion regulation and well-being. Springer, 31-47. https://doi.org/10.1007/978-1-4419-6953-8_3

Triandis, H. C., \& Gelfland, M. J. (1998). Individualism and collectivism scale (also known as the culture orientation scale). Journal of Personality and Social Psychology, 74, 118-128. https://doi.org/10.1037/0022-3514.74.1.118

Tugade, M. M. (2004). Psychological resilience and positive emotional granularity: Examining the benefits of positive emotions on coping and health. Journal of personality, 72(6), 1161-1190. https://doi.org/10.1111/j.1467-6494.2004.00294.x

Valente, R. R., \& Berry, B. J. (2015). Countering Inequality: Brazil's Movimento Sem-Terra. Geographical Review, 105(3), 263-282. https://doi.org/10.1111/j.1931-0846.2015.12078.x

Veenhoven, R. (2003). Hedonism and happiness. Journal of happiness studies, 4(4), 437-457. https://doi.org/10.1023/B:JOHS.0000005719.56211.fd

Warr, P. (1992). Age and occupational well-being. Psychology and aging, 7(1), 37. https://doi.org/10.1037/0882-7974.7.1.37

Wong, Y. T. (2001). The Chinese at work: Collectivism or individualism?

Yang, L. Q., Spector, P. E., Sanchez, J. I., Allen, T. D., Poelmans, S., Cooper, C. L., \& Antoniou, A. S. (2012). Individualism-collectivism as a moderator of the work demands-strains relationship: A cross-level and cross-national examination. Journal of International Business Studies, 43(4), 424-443. https://doi.org/10.1057/jibs.2011.58

Zheng, C., Kashi, K., Fan, D., Molineux, J., \& Ee, M. S. (2016). Impact of individual coping strategies and organisational work-life balance programmes on Australian employee well-being. The International Journal of Human Resource Management, 27(5), 501-526. https://doi.org/10.1080/09585192.2015.1020447

\section{Copyright Disclaimer}

Copyright for this article is retained by the author(s), with first publication rights granted to the journal.

This is an open-access article distributed under the terms and conditions of the Creative Commons Attribution license (http://creativecommons.org/licenses/by/3.0/). 